\title{
E-Komik Hikayat Patani: Putera Pewaris Kerajaan (Satu Analisis Tekstual, Kepentingan dan Cabaran)
}

\author{
MOHAMED NAZREEN SHAHUL HAMID \\ Universiti Utara Malaysia \\ MUHAMMAD NUR SAIFUL GHAZALI \\ Maktab Rendah Sains Mara, Arau
}

\begin{abstract}
ABSTRAK
Pada era globalisasi kini, komik fizikal telah mengalami transformasi yang memperlihatkan perubahan daripada komik yang dicetak kepada penghasilan e-komik dalam talian. Namun, kajian berkaitan ekomik masih terhad. Melihat kepada kelompongan ini, kajian ini diusahakan ke atas e-komik Hikayat Patani: Putera Pewaris Kerajaan, terbitan Dewan Bahasa dan Pustaka (DBP). Kajian ini melibatkan tiga analisis utama, iaitu tekstual, kepentingan dan cabaran. Analisis tekstual menggunakan lima prinsip komik yang diperkenalkan oleh Hall di dalam penulisannya Five Essential Principles of Comics and Cartooning. Manakala, analisis kepentingan dan cabaran menggunakan kaedah kepustakaan. Hasil analisis dalam aspek tekstual mendapati, e-komik tersebut memenuhi kelima-lima prinsip komik oleh Hall. Hal ini menunjukkan e-komik tersebut mempunyai mutu yang tinggi. Malah, ilustrasi yang dihasilkan juga kaya dengan jati diri Melayu dan tidak terpengaruh dengan sebarang teknik bentuk komik lain serta dihadirkan dengan kandungan cerita yang menarik. Dari aspek kepentingan, e-komik tersebut dapat menarik minat generasi muda untuk mempelajari teks tradisional Hikayat Patani dan sejarah Negeri Patani serta menjadi alat dalam memupuk minat generasi muda untuk membaca dan memperoleh ilmu. Jaringan internet yang lemah, penghasilan bab yang sedikit dan masalah kos yang tinggi adalah masalah yang perlu ditangani, dalam penghasilan e-komik. Justeru, kajian ini mendapati penting bagi lebih banyak e-komik berdasarkan sumber sejarah ataupun teks tradisional supaya peradaban bangsa terus terpelihara.
\end{abstract}

Kata kunci: E-komik, Hikayat Patani: Putera Pewaris Kerajaan, tekstual, kepentingan, cabaran.

\section{E-Comic of Hikayat Patani: Putera Pewaris Kerajaan (An Analysis of its Text, Importance and Challenges)}

\begin{abstract}
In the era of globalization, physical comics have undergone a transformation from being available in a printed format to the e-comics production that are accessible online. However, e-comic-related studies are still limited. Looking at this gap, this study is conducted on the e-comic, Hikayat Patani: Putera Pewaris Kerajaan, published by Dewan Bahasa dan Pustaka (DBP). This study involved three main analyses, namely on the text, importance and challenges. The textual analysis uses five comic principles introduced by Hall in his writing Five Essential Principles of Comics and Cartooning. A library research, meanwhile, was conducted to identify the importance of e-comic and challenges. The analysis in textual aspect results found that the e-comic fulfils all the five comic principles by Hall. This shows that the e-comics have a high quality. In fact, the created illustrations are filled with abundant aspects of Malay identity and not be influenced by any other form of comic technique while presenting the content using an interesting storyline. The e-comic may be indicated as vital to attract the youth generation to learn about the traditional text of Hikayat Patani and the history of the Patani state
\end{abstract}


while becoming a tool in fostering the interest among the younger generation to read and acquire knowledge. However, poor internet network, low chapter production and high cost of producing ecomics are challenges which must be overcome. Thus, this study find it is important to produce more e-comics based on historical sources or traditional texts so that the nation's civilization may continue to be preserved.

Keywords: E-comic, Hikayat Patani: Putera Pewaris Kerajaan, textual, importance, challenges.

\section{PENDAHULUAN}

Komik secara umumnya merupakan bahan bacaan yang digemari oleh golongan kanak-kanak dan remaja. Malah, terdapat juga sebahagian daripada golongan dewasa yang amat meminati bahan bacaan bergambar ini. Disebabkan kemampuan kewangan, golongan dewasa ini sering menjadikan komik sebagai koleksi seperti mana yang dilakukan penggemar buku, permainan video dan filem (Louie, 2014). Hal ini membuktikan bahawa komik mempunyai daya tarikan tersendiri, iaitu antaranya kaya dengan ilustrasi berseni tinggi. Kegilaan terhadap komik pada hari ini bertambah rancak dengan wujudnya laman-laman sesawang atau web seperti KOMIK$M$, yang menyediakan aneka ragam bahan komik secara dalam talian. Kewujudan lamanlaman sesawang yang memuat naik bahan-bahan komik dalam talian ini, telah melahirkan ekomik atau komik digital. Kini, e-komik dengan pantas telah pun menjadi bahan bacaan alternatif selain daripada buku cerita, hikayat, teks, sejarah dan buku-buku ilmiah (Allen, 2014). Malah, bagi Kirchoff dan Cook (2019), e-komik akan terus mendominasi pasaran sehingga datangnya teknologi baharu yang dapat mengubah kaedah pembacaan masyarakat dunia secara drastik.

Perkembangan pantas yang berlaku di negara-negara luar turut berlaku di Malaysia. Kini terdapat usaha dalam menghasilkan e-komik berasaskan bahan bercetak sedia ada. la dilakukan bagi menarik minat khalayak untuk membaca terutamanya bagi kisah-kisah sejarah yang sering kali dikatakan sebagai membosankan. Walau bagaimanapun, kajian terperinci dan mendalam terhadap e-komik masih kurang dilakukan oleh para sarjana (Julina \& Md. Salleh, 2020; Nurul Syazwani \& Wan Hasmah, 2018; Hamidah, 2011). Situasi ini sebenarnya adalah bertentangan dengan perkembangan pesat e-komik yang berlaku di Malaysia, yakni menyaksikan pelbagai laman sesawang yang menyajikan e-komik telah dihasilkan dan berjaya menarik ramai pengikut (Andaq Fithry, 2019). Justeru, kajian ini bertindak untuk menganalisis sebuah karya e-komik berjudul Hikayat Patani: Putera Pewaris Kerajaan terbitan Dewan Bahasa dan Pustaka (DBP) dari sudut tekstual, kepentingan dan juga cabaran. Kajian ini penting dalam mengubah persepsi negatif yang wujud terhadap komik dan e-komik yang umumnya sering dikatakan mempengaruhi tingkah laku ganas dalam kalangan kanak-kanak (Styles, 2019). Perkara-perkara tersebut dilakukan melalui penjelasan terperinci terhadap karya e-komik Hikayat Patani: Putera Pewaris Kerajaan yang mempunyai kualiti penghasilan yang tinggi dan juga bukannya sekadar picisan yang perlu dibiarkan begitu sahaja.

\section{TINJAUAN LITERATUR}

Secara umumnya, kajian ini berpaksikan kepada karya-karya komik. Oleh yang demikian, telah ditinjau beberapa kajian lepas berkaitan komik yang dilakukan oleh para sarjana. Pertama, kajian yang dijalankan oleh Julina dan Md. Salleh (2020), iaitu "Komik Selendang Siti Rugayah: Suatu Bacaan Hermeneutik Kerohanian". Kajian ini adalah tertumpu kepada komik Selendang Siti Rugayah yang dihasilkan oleh Raja Kartun Malaysia, yakni Rejabhad. Berlandaskan kajian yang bersifat kualitatif, komik tersebut telah ditafsirkan mulanya dari aspek visual dan juga 
tekstual untuk mendapatkan maksud luaran karya berkenaan. Bacaan hermeneutik kemudian pula digunakan untuk memperoleh maksud dalaman atau kerohanian karya komik Selendang Siti Rugayah. Akhirnya, ditemukan bahawa Rejabhad tidak sahaja menampilkan kisah cinta antara lelaki dengan perempuan, tetapi termasuk juga kisah naik turun iman manusia dan lenturan cinta jiwanya terhadap Sang Pencipta. Komik Selendang Siti Rugayah bukanlah sekadar cerita yang berunsur jenaka. Sebenarnya, ia juga sebuah cerita yang berkait rapat dengan perjuangan jiwa manusia untuk kembali dekat dengan Tuhannya.

Seterusnya, terdapat kajian yang dilaksanakan oleh Roslina, Normaliza, Nik Rafidah dan Roswati (2019), iaitu "Perkembangan Komik dan Animasi: Satu Kajian Perbandingan antara Melayu dan Jepun". Kajian ini telah menyorot perkembangan manga dan anime serta membandingkan kedua-duanya dengan komik dan juga animasi Melayu. Pada masa yang sama, kajian turut menemukan kerelevanan komik dan animasi Melayu di peringkat antarabangsa. Hasil kajian membuktikan bahawasanya penulisan karikatur Jepun telah pun bermula semenjak zaman pramoden Jepun, iaitu sebelum tahun 1600. Hal ini jauh lebih awal berbanding komik Melayu yang cuma boleh dirujuk seawal 1950-an. Malah, bagi komik dan animasi Melayu, garis masa yang sesuai ataupun tepat untuk membezakan perkembangannya adalah sebelum dan selepas 1980 -an. Selain itu, turut didapati bahawa komik Melayu atau lakaran berbentuk humor adalah sangat baharu.

Selain itu, terdapat juga kajian yang dilakukan oleh Nurul Syazwani dan Wan Hasmah (2020) bertajuk "Pertembungan Nilai Desa dan Kota dalam Komik Budak Kampung dan Mat Som". Kajian ini menggunakan teori sosiologi sastera untuk meneliti pengaruh sosiobudaya ke atas penciptaan karya sastera dan untuk memahami pertembungan nilai desa dan kota yang terdapat dalam komik Budak Kampung dan juga Mat Som karya Lat. Berdasarkan teori tersebut, kajian telah memperlihatkan bahawa faktor sosiobudaya dan situasi semasa kuat mempengaruhi kedua-dua komik yang dihasilkan oleh Lat. Kedua-dua komik tersebut didapati merakamkan gaya hidup dan budaya masyarakat Melayu sekitar tahun 1950-an dan 1980-an. Kajian ini juga mendapati bahawa pembangunan dan kemodenan membuatkan masyarakat tempatan semakin hilang jati diri dan nilai moral setempat.

Satu lagi kajian ialah "Penggunaan Manga dan Anime sebagai Media Pembelajaran dalam Kalangan Pelajar Bahasa Jepun di Universiti Awam Malaysia" oleh Roslina, Roswati, Hazlina dan Nor Shahila (2018). Objektif utama kajian ini adalah mengenal pasti penggunaan manga dan anime dalam kalangan pelajar di dua buah Universiti Awam (UA), iaitu Universiti Putra Malaysia (UPM) dan Universiti Malaya (UM) serta mengkaji pengaruh manga dan juga anime terhadap kehidupan mereka. Kajian berjaya menemukan bahawa pelajar perempuan lebih menggemari manga dan anime jenis seinen (remaja lelaki), manakala pelajar lelaki lebih cenderung kepada manga dan anime jenis shojo (remaja perempuan). Genre fantasi paling diminati diikuti humor, misteri, percintaan, seram dan erotisisme. Sebilangan pelajar sahaja menyatakan bahawa manga dan anime memberi pengaruh terhadap kehidupan mereka serta hampir kesemua mereka bersetuju kedua-dua bahan tersebut membantu meningkatkan kemahiran bahasa Jepun.

Penelitian terhadap komik juga turut dilakukan oleh Mohd Aswari dan Jasni (2016), "Penilaian Bahasa Visual Terhadap Faktor Penglibatan Pembaca Komik Melayu". Kajian adalah berlandaskan teori kognitif sosial dan menggunakan data komik berbahasa Melayu sebagai bahan kajian bertujuan melihat impak bahasa visual, penglibatan pembaca dan pengaruh komik kepada khalayak. Dapatan kajian menjelaskan bahawa komik berpengaruh ke atas aspek kognitif pembaca dan berupaya menerapkan bukan sahaja aspek positif tetapi juga 
turut menyelitkan unsur negatif seperti keganasan dan pertentangan moral ke dalam aspek pemikiran pembaca. Malah, juga ditemukan melalui komik, khalayak pembaca didedahkan dengan pelbagai unsur asing dan juga gaya hidup moden yang kadangkala tidak selari dengan ciri-ciri hidup masyarakat tempatan yang kuat kepada budaya Melayu Islam.

Kajian berjudul "Bahasa Slanga dalam Komik Kanak-Kanak" oleh Nasihah, Noor, Ainal dan Maizatul (2016) pula menganalisis bentuk bahasa slanga yang wujud dalam penulisan komik kanak-kanak, iaitu Siri Komik Ana Muslim yang diterbitkan oleh Ana Muslim Sendirian Berhad. Didapati bahawa, antara bentuk slanga yang digunakan oleh penulis ialah slanga yang dibentuk dari bahasa asing seperti "baby kiut", "tere", "jeles", "otai" dan slanga untuk ganti nama seperti "korang", "diorang", "diorang" dan sebagainya. Sehubungan itu, kajian ini telah menyarankan agar pihak penulis dan penerbit bahan bacaan kanak-kanak mengatur strategi untuk mengatasi masalah penggunaan bahasa slanga, agar kanak-kanak lebih kerap terdedah dengan bahasa yang baik dan seterusnya dapat melestarikan kesopanan dan juga kesantunan dalam berbahasa.

Di samping itu, terdapat juga kajian yang dilakukan oleh Hamidah (2011), iaitu "Bahasa Pemersatu Bangsa: Ragam Bahasa dalam Komik". Kajian ini menemukan ragam bahasa yang wujud dalam komik asasnya merujuk kepada ragam bahasa bebas yang berada di luar ruang lingkungan formal. Didapati juga, bahasa dalam komik yang dikaji memiliki nilai identiti kaum menerusi penggunaan slanga daerah dan slanga etnik. Sungguhpun demikian, bahasa dalam komik masih mementingkan rasa peka terhadap isu-isu yang sensitif dan tabu dalam kalangan khalayak tempatan yang terdiri daripada pelbagai etnik. Dalam pengutaraan unsur kelucuan dan juga kejenakaan melalui komik, kartunis secara bijak mengasosiasikan unsur persekitaran dunia kartun dan melahirkan humor yang mengandungi mesej dan kritikan sosial untuk aspek kesedaran pembaca menerusi ragam bahasa yang digunakan.

Kajian berkaitan komik di Malaysia banyak memperlihatkan aspek penggunaan bahasa dan pemikiran yang disampaikan melalui teks dan menggunakan data komik dalam bentuk konvensional atau bercetak. Sehubungan itu, kajian ini meneliti komik melalui bentuk media baharu, iaitu e-komik yang terdapat dalam laman web DBP, yakni Hikayat Patani: Putera Pewaris Kerajaan. Penelitian ini meliputi aspek tekstual, kepentingan dan cabaran e-komik mengadaptasi karya berunsur sejarah kepada khalayak.

\section{KOMIK DAN E-KOMIK}

Komik secara umumnya merujuk kepada media yang mengekspresikan naratif atau idea-idea lain menggunakan rangkaian gambar pegun dan kebiasaannya digabungkan dengan teks yang pelbagai. Pemaknaan ini menghampiri apa yang dikatakan oleh Eisner (2008), komik itu ialah satu seni yang mempunyai gambar berurutan atau "sequential art". Sementara itu, menurut McCloud (2001) komik ialah gambar atau lambang lain yang disusun dalam urutan tertentu bertujuan untuk memberikan informasi dan mendapat tindak balas secara langsung daripada pembaca. Komik, lazimnya dicetak di atas kertas dan dilengkapi dengan teks dan dialog, serta diterbitkan dalam bentuk buku atau secara eceran dalam majalah dan surat khabar (Roslina, Nor Shahila, Hazlina \& Normaliza, 2015).

Komik selalunya berbentuk urutan panel gambar. Perantis teks yang ada dalam komik seperti belon ucapan atau speech balloons, kapsyen dan onomatopia dapat menunjukkan dialog, naratif, kesan bunyi dan maklumat-maklumat lain (McCloud, 2011). Selain itu, dalam komik, ukuran dan susunan panel amat menyumbang kepada penceritaan yang ingin ataupun mahu disampaikan. Oleh yang demikian, pengkarya komik harus peka terhadap alur cerita dalam memastikan mesej adalah selari dengan gambar yang dipaparkan. Penghasilan kartun 
dan juga bentuk ilustrasi lain adalah kaedah membuat gambar yang paling lazim dalam komik. Manakala, "fumetti" adalah kaedah yang menggunakan gambar fotografi untuk menghasilkan komik (Chelsea, 2001). Walau bagaimanapun, kaedah "fumetti" ini jarang digunakan kerana pengkarya komik gemar untuk melukis sendiri berbanding menggunakan gambar fotografi yang dilihat sebagai tiada keaslian dan melanggar norma komik.

Sejarah komik mempunyai galur yang berbeza mengikut latar budaya sesuatu negara. Namun, komik dapat dikatakan berkembang terutama di Amerika Syarikat pada pertengahan abad ke-20. Kemudian, diikuti oleh Eropah Barat khususnya di Perancis dan Belgium. Dalam masa yang sama, komik juga menapak kukuh di Jepun sehingga ke hari ini dengan penghasilan komik berlatarkan budaya dan gaya tersendiri yang dikenali sebagai manga. Di Malaysia, komik mula dihasilkan pada tahun 1950-an dan kini versi cetaknya sedang mengalami kemerosotan (Muliyadi, 2015).

Di samping itu, komik juga mempunyai jenis yang berbeza, iaitu komik strip dan juga komik buku. Komik strip ialah potongan komik yang terdiri daripada beberapa panel gambar yang biasanya ditemui dalam majalah dan akhbar seperti yang dapat diteliti melalui Rajah 1 di bawah:

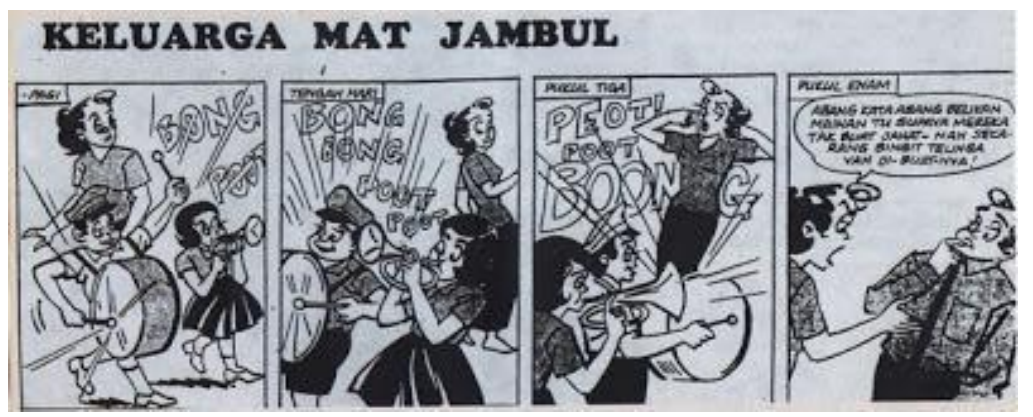

Rajah 1: Contoh komik strip yang disiarkan dalam akhbar Berita Harian pada tahun 1980-an.

Sumber: http://akujohan.blogspot.com/2008/01/raja-hamzah-kartun-mat-jambul.html

Komik buku pula merujuk kepada komik yang telah dibukukan dan biasanya dihasilkan secara bersiri seperti yang boleh dirujuk melalui Rajah 2 berikut:

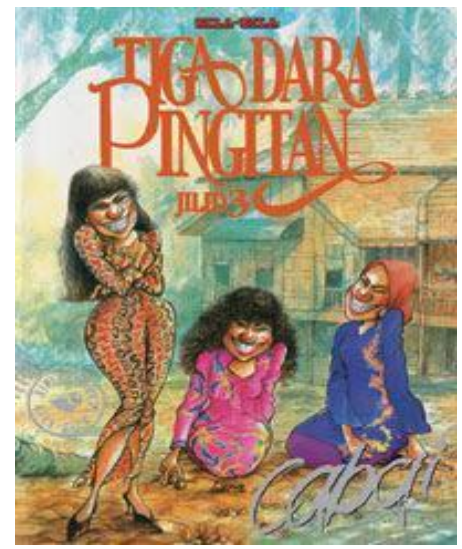

Rajah 2: Komik buku bersiri Tiga Dara Pingitan keluaran syarikat penerbitan Gila-Gila. Sumber: http://akujohan.blogspot.com/2007/08/

Seterusnya, harus difahami bahawa kombinasi lukisan dan gambar dalam komik telah membentuk sebuah naratif yang boleh diamati dan dinikmati. Malah, komik juga dihasilkan dengan kehadiran watak, latar, plot dan tema tertentu dalam menyampaikan ceritanya. Hal 
ini membuatkan komik dapat dikatakan sebagai sebuah karya gabungan, iaitu antara seni visual/tampak dan sastera. Malah, McCloud (1993), menganggap komik memiliki potensi bagi diangkat sebagai karya sastera seperti novel dan cerpen. Hal ini dikatakan demikian kerana, penciptaan komik ini dapat juga memberikan khalayak pembacanya gambaran tentang isuisu kehidupan, masa dan cara pandang dunia melalui karya. Dalam erti kata lain, komik seperti karya sastera dapat dianggap sebagai dokumen sosial yang merakam perubahan zaman.

Selesai mengenai komik, perbincangan beralih pula kepada e-komik yang menjadi fokus bagi kajian ini. E-komik atau juga dikenali sebagai komik digital, atau komik elektronik pula adalah merujuk kepada komik yang dibangunkan, diedarkan, dipasarkan dan juga dijual dalam bentuk digital sepenuhnya (Petersen, 2011). Komik jenis ini telah menjadi suatu bahan alternatif kepada yang dicetak secara konvensional. Pada awal kemunculan e-komik, didapati pembangun e-komik masih mengikut konsep asal penciptaan komik bercetak. Struktur dan bentuk penceritaan yang digubah masih dalam corak yang lama. Hanya dari sudut penjualan dan penyebaran bahan bacaan ini berubah medium, iaitu daripada bercetak kepada digital.

Walau bagaimanapun, setelah dunia menerima kemajuan dalam bidang teknologi dan pendigitalan, muncul e-komik yang dibangunkan sepenuhnya dengan menggunakan kaedah atau teknologi digital. Dalam erti kata lain, e-komik tidak lagi dilukis tangan dan kemudian ia didigitalkan. Sebaliknya, e-komik dilukis dalam komputer, tab, iPad dan sebagainya, kemudian terus dipasarkan dalam bentuk digital. Pembaca harus mempunyai komputer, telefon pintar dan alat peranti lain untuk membaca e-komik ini. Peter Gilis (Styles, 2019) adalah pengkarya pertama yang membangunkan e-komik yang pertama bertajuk Shatter pada tahun 1985, iaitu dengan menggunakan komputer Apple Macintosh generasi pertama.

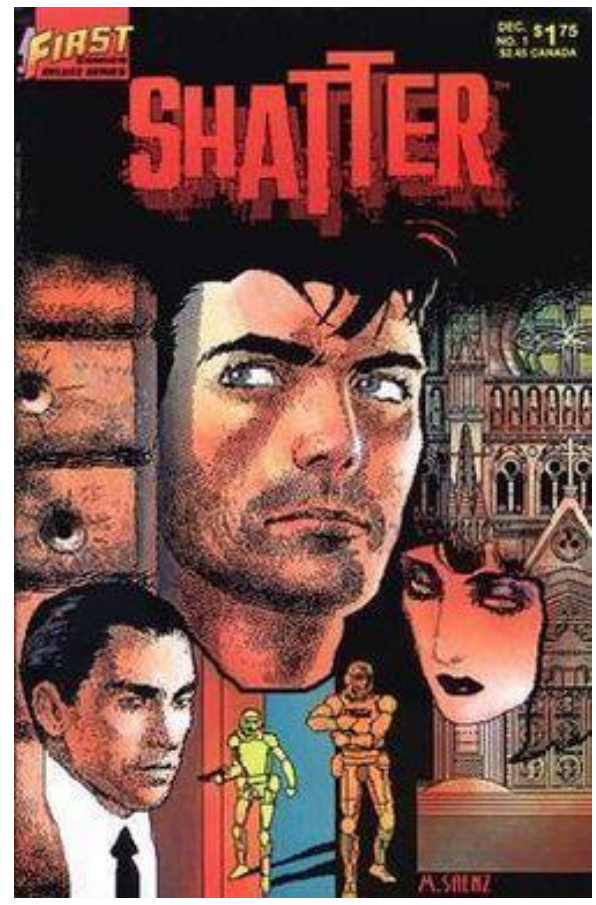

Rajah 3: Shatter, e-komik pertama.

Sumber: https://en.wikipedia.org/wiki/Shatter (digital comic)\#/media/File:Shatter (digital comic).jpg

Meskipun begitu, pada masa itu komik yang dihasilkan sepenuhnya secara digital tidak begitu mendapat sambutan daripada khalayak pembaca. Hal ini demikian kerana, pembaca masih gemarkan pembacaan komik secara konvensional. Malah, liputan internet yang agak terhad pada masa itu turut menghalang e-komik daripada dinikmati oleh khalayak yang lebih 
luas. Dalam keadaan demikian, Syarikat Voyager, umpamanya, telah mendigitalkan komik bercetak bertajuk The Compete Maus kepada bentuk CD-ROM pada tahun 1994 (Petersen, 2011).

Perkembangan teknologi digital yang pesat dan meluas memperlihatkan penggunaan telefon pintar dan komputer yang semakin meningkat telah menyebabkan syarikat-syarikat penerbitan komik melakukan adaptasi dengan mengeluarkan e-komik. Malah, penurunan hasil penjualan komik bercetak dan pelanggaran hak cipta turut mendesak syarikat-syarikat penerbitan menyesuaikan diri dengan era digital (Miller, 2013). Di peringkat awal, pada tahun 2009, Amerika Syarikat mengungguli penerbitan e-komik. Hal ini dibantu oleh populariti filemfilem adaptasi komik Marvel seperti Iron Man (2008), Captain America: The First Avengers (2011), Thor (2011) dan sebagainya. Komik yang dahulunya mengalami kemerosotan, terus meledak naik, terutamanya dalam versi digital. Kemudiannya, Jepun mengikuti perubahan ini walaupun pada awalnya mempunyai kesulitan dalam menyediakan laman sesawang atau web perkongsian e-komik (Thompson, 2014).

Di Malaysia, e-komik bermula dari tahun 2009 ke atas. Antara pelopor terawal ialah syarikat Gempak Starz yang mula menjual e-komik melalui laman web. Perkembangan ini berlaku apabila permintaan komik bercetak oleh khalayak tempatan semakin berkurangan saban tahun. Malah, syarikat penerbitan MOY, yang terkenal dengan komik majalah Ujang dan Apo? pada tahun 2015, mengalami masalah kewangan yang teruk ekoran hasil penjualan komik bercetak yang sudah tidak laris seperti dahulu. Namun, kini kartunis atau pengkarya di bawah syarikat penerbitan MOY tersebut, bangkit menghasilkan syarikat penerbitan baharu, iaitu Bekazon dengan penjualan komik-komik secara digital sepenuhnya.

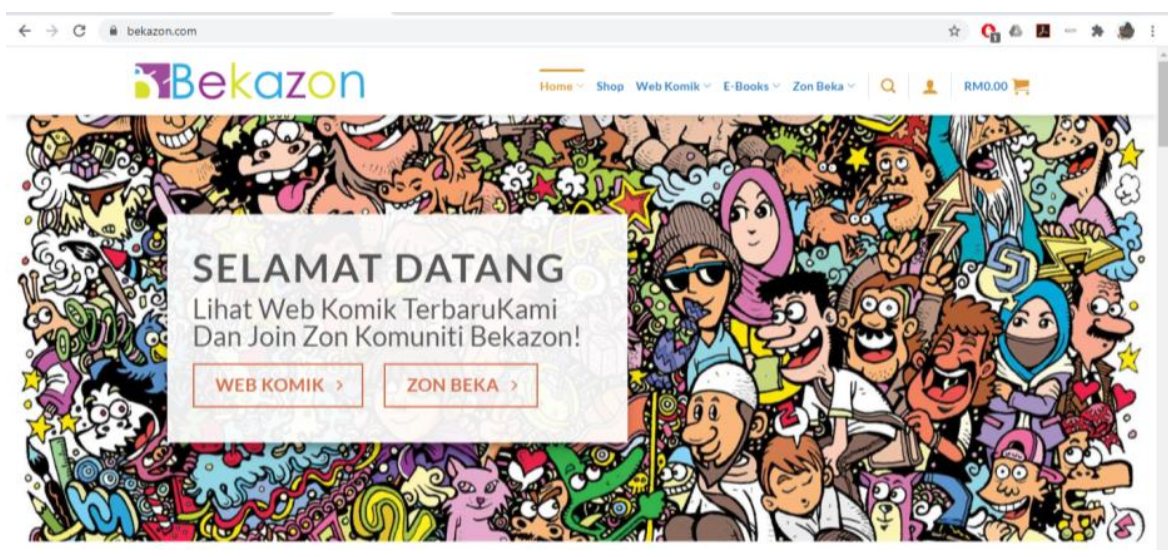

Rajah 4: Laman web Bekazon yang menjual e-komik.

Sumber: https://bekazon.com/

Kini, terdapat pelbagai laman web tempatan yang menjual e-komik dengan gaya dan jati diri tempatan. Misalnya, matkomik.com, komikm.com, dan lain-lain lagi. Bahkan, pihak Kementerian Kesihatan Malaysia (KKM) turut menyediakan satu laman web komik (http://mohklik.moh.gov.my/) dengan usaha untuk mengajar kanak-kanak tentang keselamatan makanan. Perkembangan e-komik yang berlaku di Malaysia ini memperlihatkan tahap ketersediaan syarikat penerbitan negara yang tinggi untuk bersaing dengan karya luar. Perkembangan ini perlu diteruskan agar bakat warga tempatan dapat diketengahkan ke peringkat lebih tinggi atau global. 


\section{E-Komik Hikayat Patani: Putera Pewaris Kerajaan}

Dalam kajian ini, e-komik Hikayat Patani: Putera Pewaris Kerajaan terbitan DBP telah dipilih untuk dianalisis dari segi tekstual dan juga dari konteks kepentingan dan cabaran yang dihadapi. E-komik ini telah dimuat naik dalam laman web Ruang Multimedia DBP yang dibangunkan menggunakan WordPress.com. Pada asasnya, usaha yang dilakukan oleh DBP ini ialah satu inisiatif segar dalam menarik minat masyarakat terhadap teks tradisional kesusasteraan Melayu, Hikayat Patani.

Hikayat Patani merupakan satu daripada karya agung dalam khazanah persuratan alam Melayu. Teks ini dipercayai telah ditulis pada tahun 1838 (Teeuw \& Wyat, 1970). la secara umumnya memaparkan atau mengisahkan sejarah tentang bangsa Melayu di Patani. Pengarang dengan tertibnya menceritakan kepada khalayak tentang sejarah kelahiran dan perkembangan serta kejatuhan sistem beraja kerajaan Patani.

Patani dahulu adalah sebuah negeri Melayu sama seperti negeri-negeri Melayu ada di Semenanjung Malaysia kini. Namun, disebabkan penjajahan Siam-Thai, Patani telah pun dipecahkan kepada beberapa wilayah kecil seperti yang wujud sekarang atau dikenali dunia sebagai Selatan Thailand (Mohamed Nazreen, 2020). Hal ini kebanyakannya tidak diketahui oleh masyarakat Melayu Nusantara, termasuklah yang tinggal di Malaysia. Justeru, orang Melayu Patani kerap kalinya dikatakan sebagai bangsa Siam, walhal mereka adalah bangsa Melayu beragama Islam yang masih hidup dalam lingkungan penjajahan bangsa Thai (Nik Anuar Nik Mahmud, 2006; Mohd. Zamberi Abdul Malek, 2017).

Lantaran itu, kepentingan Hikayat Patani kepada rakyat Patani khususnya golongan muda dan juga kepada masyarakat Melayu keseluruhannya, tidak boleh dinafikan. Teks ini merakam satu sejarah kegemilangan tamadun negeri Melayu yang harus diketahui oleh generasi sekarang dan masa hadapan. Malah, kesemua hal ini memberikan gambaran yang jelas tentang sebab utama teks Hikayat Patani menjadi pilihan penting bagi penghasilan ekomik terawal oleh DBP berbanding teks-teks hikayat yang lain.

Oleh yang demikian, usaha Bahagian Multimedia, DBP mengambil teks Hikayat Patani untuk dijadikan sebagai e-komik adalah amat bertepatan dan dialu-alukan. Berdasarkan rekod yang tercatat, e-komik Hikayat Patani: Putera Pewaris Kerajaan telah dimuat naik pada 30 September 2010 dan telah dikongsi di media sosial Facebook hingga setakat 30 September 2020 sebanyak 150 perkongsian. Langkah yang diambil oleh DBP untuk menggunakan media sosial dalam mempromosikan e-komik ini amat sesuai kerana media sosial membuatkan proses penyebarannya menjadi luas dan pantas. Hal ini dikatakan demikian kerana, melalui media sosial seperti Facebook, e-komik tersebut dapat diakses melalui komputer dan telefon pintar serta lain-lain alat peranti pada bila-bila masa dan di mana sahaja.

Secara selayang pandang, didapati e-komik Hikayat Patani: Putera Pewaris Kerajaan ini mempunyai kredibilitinya yang tersendiri. Hal ini demikian kerana, Sasterawan Negara Dato`Anuar Rihdwan telah bertindak sebagai penulis skrip dan Faisal Jalil pula berperanan sebagai pelukis ilustrasi. Tambahan pula, e-komik ini dihasilkan berdasarkan teks Hikayat Patani yang sebenar (selenggaraan Ali Majod dan Siti Hawa Haji, 1992). Berikut adalah kulit depan e-komik Hikayat Patani: Putera Pewaris Kerajaan (Rajah 5) dan juga laman webnya (Rajah 6): 


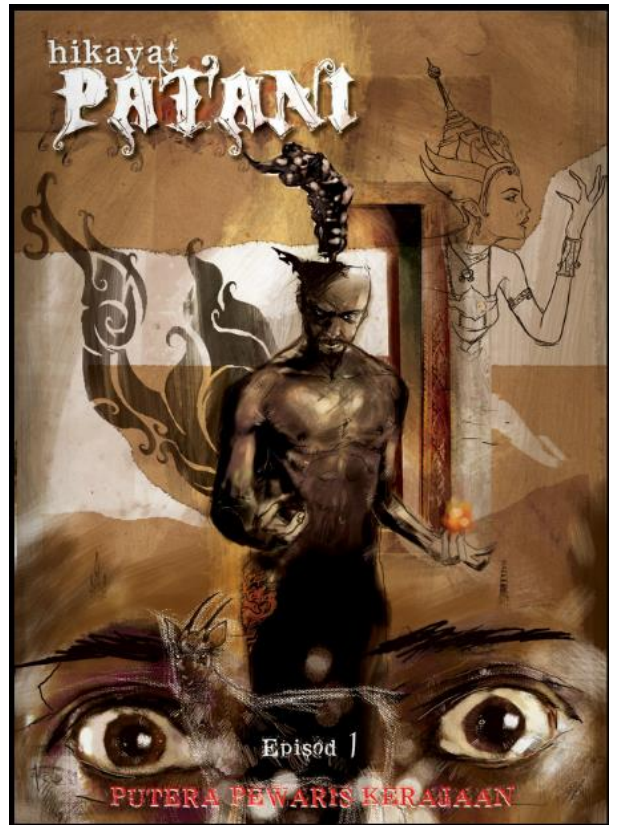

Rajah 5: Kulit depan e-komik Hikayat Patani: Putera Pewaris Kerajaan. Sumber: https://www.webtoons.com/en/challenge/hikayat-patani/

Berdasarkan Rajah 5, hampir keseluruhan kulit depan e-komik ini berona coklat. Manakala, lukisan yang dilakarkan ialah dalam bentuk surealisme. Tona warna yang serba coklat ini amat sinonim dengan warna-warna naskhah lama. Hal ini demikian kerana, kulit hadapan naskhah lama lazimnya diperbuat daripada kulit haiwan yang lama kelamaan akan menjadi warna coklat. Melalui warna yang dipamerkan, pembaca mendapat gambaran awal bahawa e-komik berkisarkan tentang penceritaan hikayat. Tambahan lagi, lakaran kulit depan e-komik dalam bentuk surealisme bertujuan untuk menyampaikan mesej melalui gabungan imej yang berunsurkan imaginasi. Dalam seni rupa, karya-karya berbentuk surealisme menonjolkan lukisan dengan objek yang memberi kesan aneh bagaikan dalam alam mimpi (Sofyan, Sukarman, Hasnawati \& Muhammad Muhaemin, 2020). Malah, kulit depan e-komik ini juga telah menampilkan lakaran Keris Hulu Pekaka yang merupakan keris asal negeri Patani (Abdul Muati, 2015).

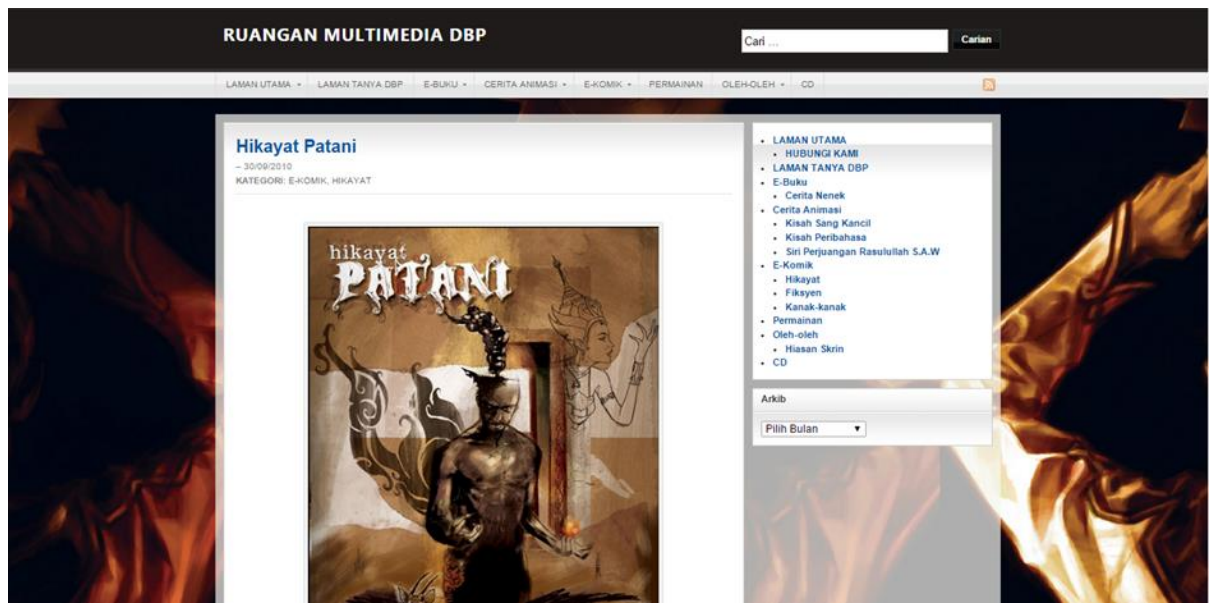

Rajah 6: Laman sosial WordPress yang digunakan untuk memuat naik e-komik Hikayat Patani: Putera Pewaris Kerajaan.

Sumber: https://www.webtoons.com/en/challenge/hikayat-patani/ 
Rajah 6 merupakan tangkap layar laman web Laman Multimedia DBP. Laman web ini telah memuatkan e-komik Hikayat Patani: Putera Pewaris Kerajaan yang boleh dibaca secara digital tanpa perlu mencetak. Selain itu, laman web ini juga menawarkan beberapa bahan bacaan lain seperti e-buku, cerita animasi dan permainan.

\section{METODOLOGI KAJIAN}

Kajian ini menggunakan prinsip-prinsip dalam komik yang diperkenalkan oleh C. Michael Hall (2014) untuk melakukan analisis tekstual terhadap e-komik Hikayat Patani: Putera Pewaris Kerajaan. Manakala, analisis kepentingan dan cabaran e-komik tersebut dilakukan dengan kaedah kepustakaan dengan merujuk kepada bahan-bahan rujukan yang berkaitan.

\section{PRINSIP-PRINSIP DALAM E-KOMIK}

Seperti yang telah dibincangkan, komik merupakan bahan bacaan yang menggabungkan seni lukisan dan bahasa bertulis, visual dan teks, mengikut susunan-susunan yang sesuai dalam menyampaikan makna yang ada kepada khalayak pembaca. Tahap kefahaman terhadap suatu komik yang dibaca adalah amat dipengaruhi oleh ilustrasi dan bahasa bertulis yang digunakan oleh penulis skrip serta pelukis ilustrasi komik. Oleh itu, dapatlah dikatakan bahawa semakin sesuai penggunaan ilustrasi dan bahasa bertulis dalam penghasilan sesebuah komik, semakin bertambah mutu karya dan minat pembaca.

Sehubungan dengan itu, prinsip-prinsip dalam komik yang diperkenalkan oleh Hall (2014) amat tepat digunakan dalam melakukan analisis tekstual terhadap e-komik Hikayat Patani: Putera Pewaris Kerajaan. Hall (2014) telah menggariskan lima prinsip yang perlu ada dalam penghasilan sesebuah komik atau e-komik. Prinsip-prinsip ini adalah ekspresi, reka bentuk, gerak isyarat (gesture), dialog dan transisi (transition). Bagi Hall (2014), kelima-lima prinsip ini perlu dikuasai untuk menghasilkan komik dan e-komik yang bermutu tinggi. Lima prinsip adalah dibincangkan seperti berikut:

\section{Ekspresi dan Reka Bentuk}

Bagi prinsip pertama dan kedua, Hall (2014) telah membincangkannya secara serentak kerana wujudnya perkaitan yang rapat antara kedua-dua prinsip tersebut. Prinsip ekspresi dalam komik merupakan gambaran yang memperlihatkan air muka terhadap wajah karakter yang menunjukkan perasaan dalaman sesuatu karakter. Melalui ekspresi, khalayak pembaca dapat memahami emosi yang sedang dialami oleh karakter yang telah dilukis oleh pelukis.

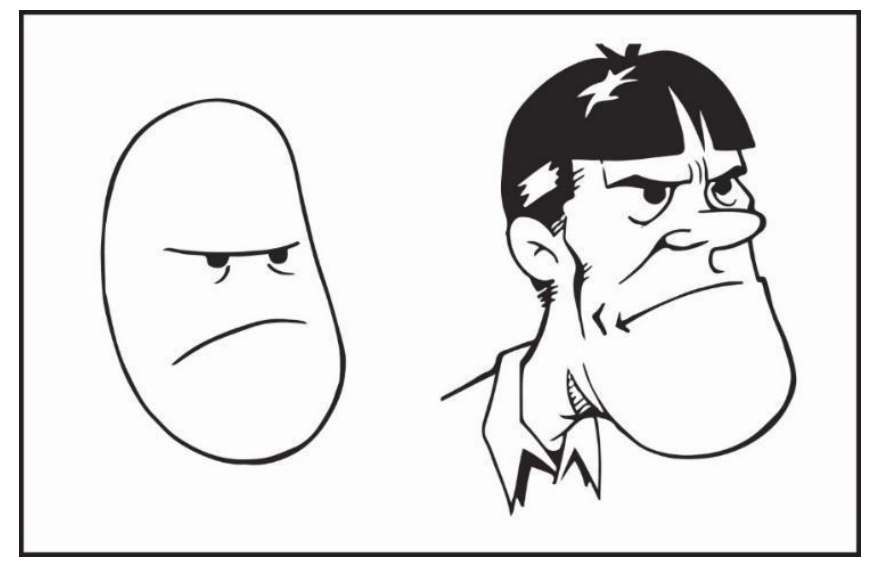

Rajah 7: Dua ilustrasi wajah yang menunjukkan ekspresi.

Sumber: Hall, C. M. (2014). A comic book for beginner. HarperCollins Publisher Inc. 
Merujuk kepada Rajah 7, ilustrasi kedua-dua karakter wajah tersebut mempunyai ekspresi emosi yang sama dan serupa. Namun, yang membezakan kedua-dua ilustrasi wajah itu adalah kehalusan reka bentuk, iaitu melibatkan "shading" dan garisan. Oleh itu, prinsip awal dalam komik ialah ekspresi dan reka bentuk. Setelah ekspresi dikenal pasti sesuai dengan jalan cerita, pelukis perlu melengkapkan reka bentuk bagi menampakkan wajah watak yang lengkap. Selain itu, harus diketahui bahawa, prinsip reka bentuk tidak hanya terhad kepada wajah manusia sahaja. la juga boleh meliputi binatang, kereta, rumah dan sebagainya.

\section{Gerak Isyarat}

Prinsip gerak isyarat dalam komik digunakan oleh pelukis ilustrasi bagi memberikan gambaran terhadap bahasa badan. Prinsip ini merupakan salah satu bentuk ekspresi yang melibatkan keseluruhan anggota badan bagi tujuan penyampaian makna. Melalui gerak isyarat pembaca dapat memahami gambaran aksi/pergerakan yang sedang dialami oleh karakter yang telah dilukis oleh pelukis ilustrasi.

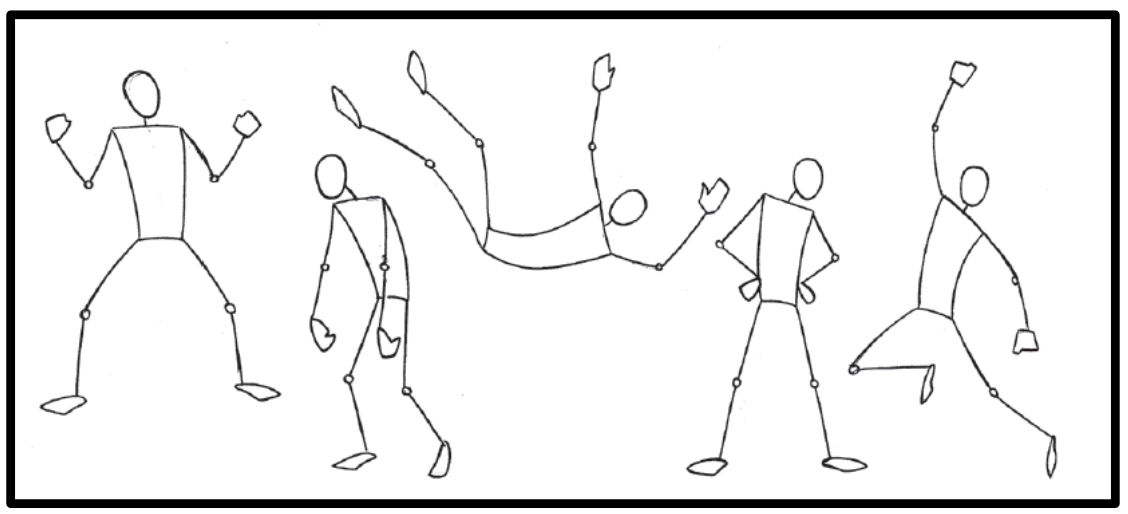

Rajah 8: Ilustrasi anatomi asas yang menujukkan gerak isyarat.

Sumber: Hall, C. M. (2014). A comic book for beginner. HarperCollins Publisher Inc.

Rajah 8 menunjukkan "stick figure" dalam pelbagai posisi dan gaya yang diekspresi oleh karakter. Meskipun, hanya lukisan "stick figure", namun prinsip gerak isyarat yang ada pada ilustrasi tersebut dapat difahami oleh pembaca. Lukisan "stick figure" ini kemudian akan dikemaskan hingga melahirkan lukisan seperti dalam Rajah 9 berikutnya:

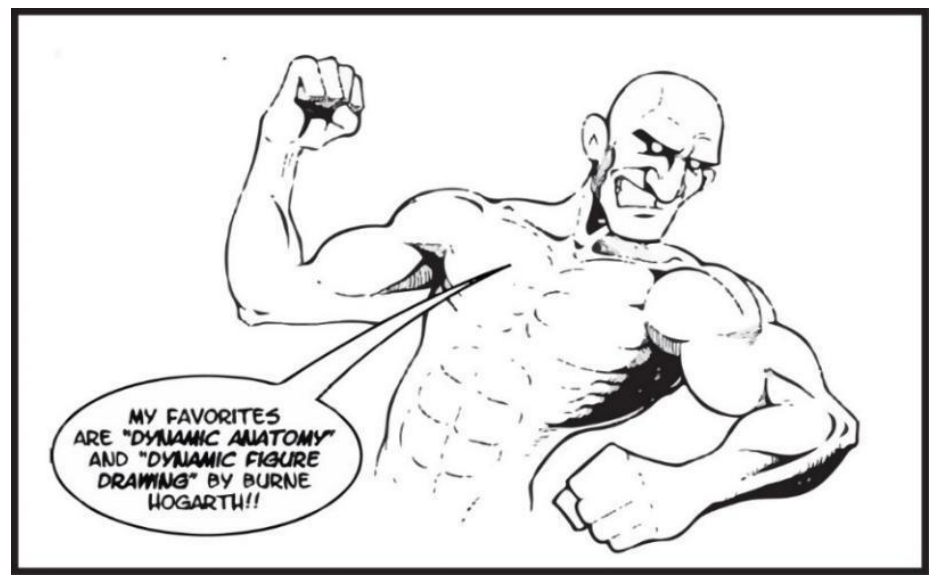

Rajah 9: Ilustrasi anatomi dinamik yang menunjukkan gerak isyarat.

Sumber: Hall, C. M. (2014). A comic book for beginner. HarperCollins Publisher Inc. 
Merujuk kepada Rajah 9, terdapat ilustrasi anatomi dinamik seorang lelaki. Berbeza daripada anatomi "stick figure", reka bentuk dalam gerak isyarat Rajah 9 lebih terperinci dan halus sehingga menonjolkan identiti karakter yang dilukis.

\section{Dialog}

Prinsip dialog dalam komik menggambarkan percakapan karakter yang telah diilustrasikan. Dalam komik, dialog selalu digambarkan dalam "balloons" atau belon pengucapan. Dialog dalam komik akan bersama dengan ilustrasi untuk menyampaikan maksud kepada pembaca. Walaupun pelukis ilustrasi melukis karakter atau ikon dengan reka bentuk yang terperinci, bahasa bertulis atau dialog akan tetap bersama dengan ilustrasi dalam usaha menyampaikan penceritaan, terutamanya bagi komik atau e-komik bersiri.

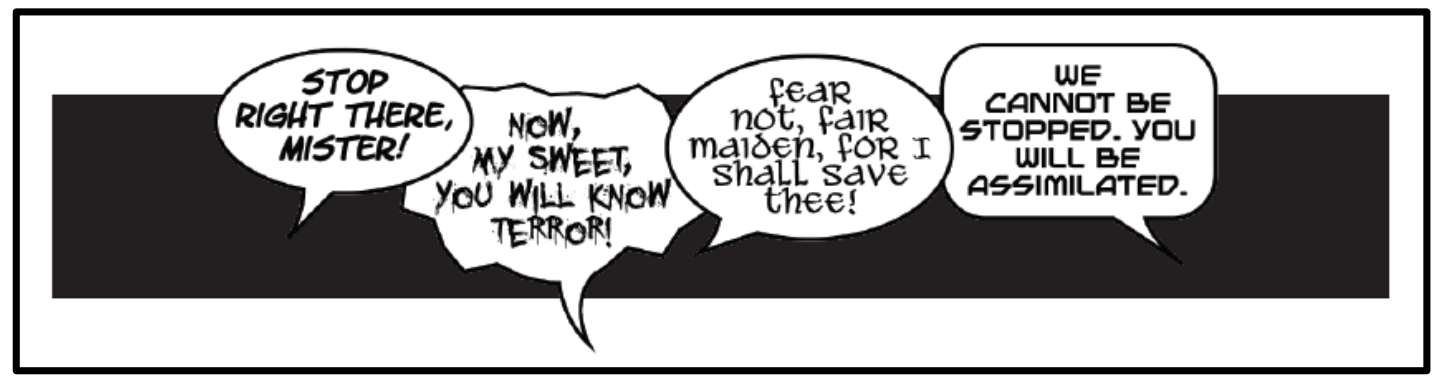

Rajah 10: Dialog (percakapan karakter) yang disampaikan dalam belon pengucapan.

Sumber: Hall, C. M. (2014). A comic book for beginner. HarperCollins Publisher Inc.

Berdasarkan Rajah 10, mereka bentuk dialog juga merupakan satu proses seni. Hal ini dikatakan demikian kerana, penghasilan dialog, iaitu melibatkan perkataan dan belon pengucapan dilakukan dalam bermacam-macam bentuk mengikut kesesuaian. Dialog perlu direka bentuk mengikut penyampaian karakter atau watak agar makna yang mahu ditonjolkan oleh penulis skrip adalah jelas. Misalnya, reka bentuk belon pengucapan bagi emosi marah adalah berbeza dengan reka bentuk untuk emosi sedih. Rekaannya tidak boleh berbentuk statik atau berbentuk sama sahaja kerana boleh mengelirukan pembaca.

\section{Transisi}

Prinsip terakhir dalam komik ialah transisi. Prinsip ini dapat dilihat melalui setiap imej atau panel yang mengandungi situasi penting yang diatur seperti sebuah jalan cerita. Apabila panel diletakkan dalam susunan yang tepat, pembaca akan mudah untuk memahami jalan cerita yang sedang disampaikan atau digerakkan seperti yang boleh diteliti menerusi Rajah 11 di bawah: 

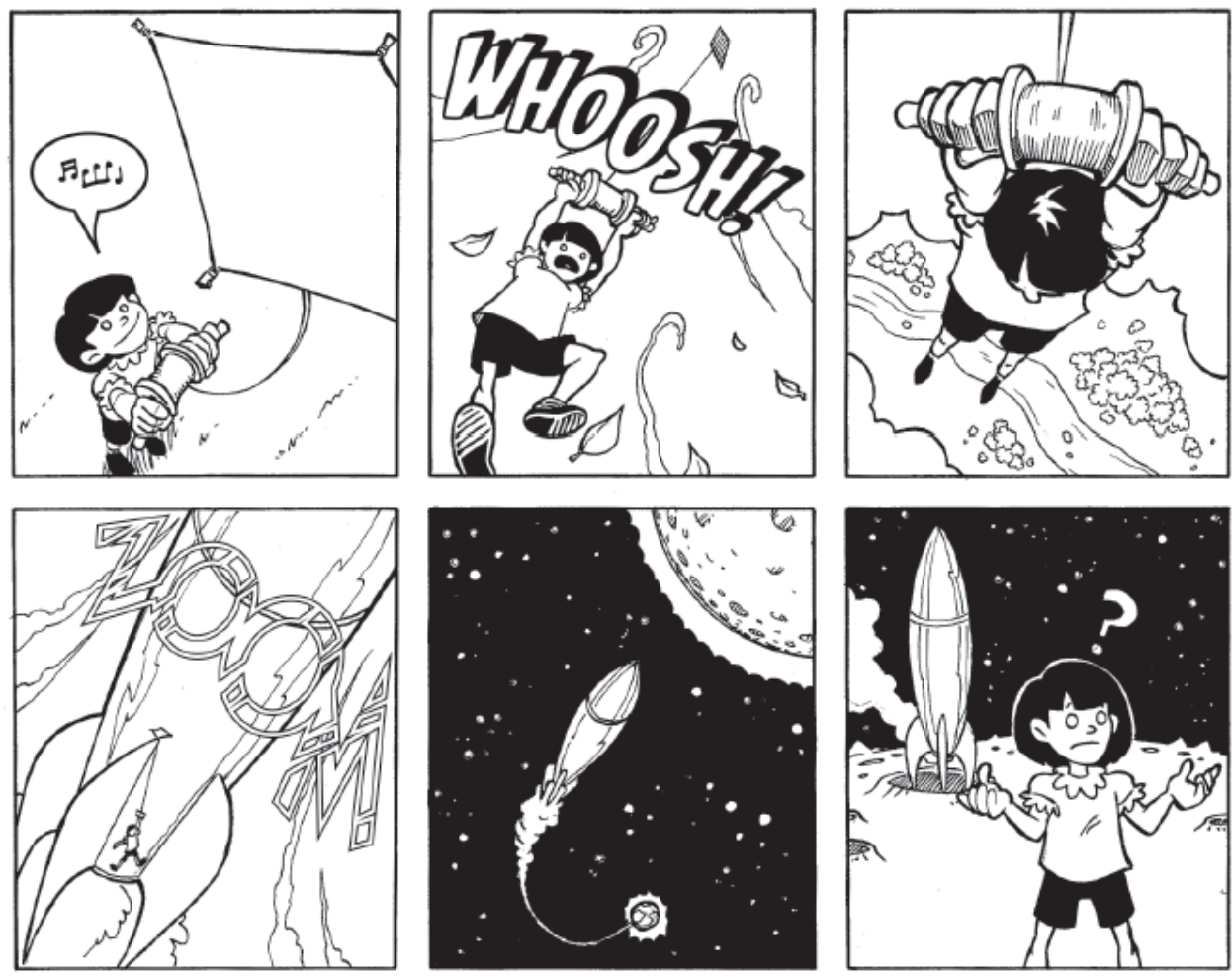

Rajah 11: Layout yang dipengaruhi oleh prinsip transisi.

Sumber: Hall, C. M. (2014). A comic book for beginner. HarperCollins Publisher Inc.

Dalam Rajah 11, pembaca dapat melihat beberapa panel yang diatur secara berurutan dari kanan ke kiri. Panel merupakan bahagian-bahagian segmen yang mengandungi babak. Terdapat panel yang mempunyai saiz yang berlainan antara satu sama lain. Saiz panel yang berbeza membawa maksud yang tertentu dan hal ini sememangnya disengajakan oleh pelukis ilustrasi komik. Panel yang lebih besar menggambarkan peristiwa yang penting. Manakala, panel yang kecil menggambarkan tentang pemikiran watak ataupun peristiwa-peristiwa atau hal sampingan dalam penceritaan.

Begitulah lima prinsip komik yang diperkatakan oleh Hall (2014). la akan digunakan dalam melakukan analisis tekstual ke atas e-komik Hikayat Patani.

\section{PERBINCANGAN DAN DAPATAN KAJIAN}

Perbincangan dan dapatan kajian akan terbahagi kepada tiga aspek penting, iaitu analisis tekstual, kepentingan dan cabaran.

\section{ANALISIS TEKSTUAL E-KOMIK HIKAYAT PATANI: PUTERA PEWARIS KERAJAAN}

E-komik Hikayat Patani: Putera Pewaris Kerajaan umumnya telah memaparkan kepada khalayak pembaca tentang institusi beraja Melayu di Negeri Patani. Kisah tentang institusi beraja ini dapat diteliti melalui perpindahan takhta, yakni daripada Raja Phaya Tu Kerub kepada Raja Phaya Tu Naqpa.

Perpindahan takhta itu berlaku disebabkan oleh kemangkatan Raja Pyaha Tu Kerub. Seterusnya, e-komik ini juga turut mengisahkan tentang kemunculan kerajaan Melayu Patani pada suatu masa dahulu. Bermula dari sebuah kerajaan Melayu di Kota Mahligai, seterusnya berpindah ke Negeri Patani disebabkan oleh peristiwa semasa berburu. 


\section{Institusi Beraja Melayu Negeri Patani}

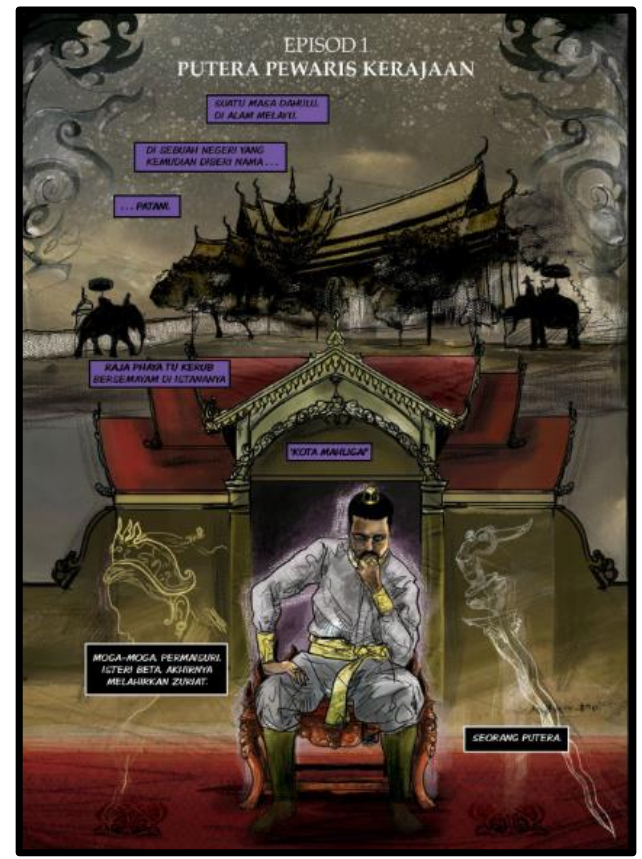

Rajah 12: Halaman pertama e-komik Hikayat Patani: Putera Pewaris Kerajaan.

Sumber: https://en.wikipedia.org/wiki/Shatter (digital comic)\#/media/File:Shatter (digital comic).jpg

Halaman pertama e-komik Hikayat Patani: Putera Pewaris Kerajaan yang ditunjukkan melalui Rajah 12, dimulakan dengan paparan ilustrasi dengan gaya surealisme. Apabila pelukis ilustrasi melukis dengan gaya surealisme, khalayak pada umumnya perlu memahami bahawa cerita pada halaman ini mempunyai unsur yang nyata dan bukan nyata, iaitu angan-angan, pemikiran, imbas semula dan lain-lain lagi. Ilustrasi dengan gaya tersebut secara umumnya sukar untuk ditimba makna dan juga apresiasinya. Hal ini dikatakan demikian kerana, tidak semua khalayak pembaca mempunyai pengetahuan ilmu atau prinsip seni yang tinggi.

Dalam Rajah 12, pelukis telah memaparkan ilustrasi waktu malam dengan paparan sebuah istana yang gah dan megah. Di hadapan istana tersebut, terdapat lakaran dua ekor gajah yang masing-masing ditunggangi oleh pengawal. Gajah yang bertubuh besar dalam Alam Melayu mewakili pemerintah yang mempunyai kuasa dan kekayaan (Eizah, 2019). Oleh itu, lakaran tersebut memberi gambaran bahawa Negeri Patani merupakan negeri Melayu yang ampuh dan kukuh dari segi kepimpinan dan ekonomi pada waktu itu. Selain itu, dalam Rajah 12 terdapat juga imej Raja Phaya Tu Kerub yang sedang bersemayam di singgahsana dan dalam postur sedang memikirkan sesuatu. Hal ini dapat dijelaskan lagi dengan lakaran imej seorang wanita secara samar di sebelah kanan baginda dan disertakan dengan belon pengucapan berbentuk segi empat dengan dialog "Moga-moga permaisuri, isteri beta akhirnya melahirkan zuriat". Dalam pada itu, terdapat lakaran imej Keris Hulu Pekaka secara samar di sebelah kiri baginda dalam Rajah 12. Lakaran imej keris ini turut disertakan dengan pemeri atau dialog "Seorang putera". Keris merupakan lambang kepada alat kebesaran Melayu yang sangat dimuliakan (Ibrahim, 1987). Maka, Raja Phaya Tu Kerub dalam Rajah 12 amat mengharapkan permaisuri melahirkan seorang putera yang dapat mewarisi kerajaan naungannya. Sekiranya baginda raja tidak mendapat seorang anak lelaki, maka kerajaannya negeri Patani akan berakhir. Lakaran ilustrasi imej yang digabung jalinkan dengan kapsyen itu amatlah tepat dalam menggambarkan citra budaya Melayu. 
Berdasarkan ilustrasi pelukis yang datangnya dengan perlambangan seperti tersebut, prinsip dialog adalah amat penting dalam penghasilan komik dan e-komik. Sasterawan Negara Anuar Rihdwan sebagai penulis skrip komik ini telah pun mengukuhkan ilustrasi yang telah dihasilkan oleh pelukis ilustrasi dengan pemeri atau dialog yang ringkas tetapi berkesan, iaitu sesuai dengan sifat komik itu sendiri. Bahkan, pada awalnya juga Sasterawan Negara Anuar Ridhwan memulakan komik ini dengan pemeri yang berikut (Rajah 13 ):

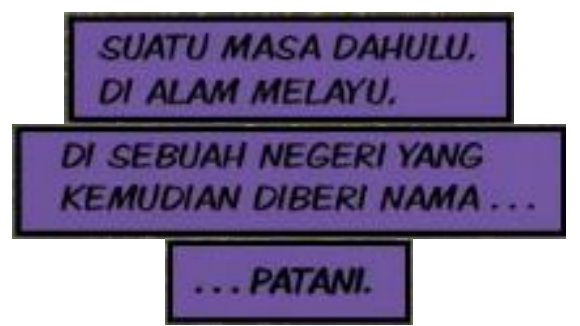

Rajah 13: Dialog atau pemeri awal, dalam e-komik Hikayat Patani: Putera Pewaris Kerajaan Sumber: https://en.wikipedia.org/wiki/Shatter (digital comic)\#/media/File:Shatter (digital comic).jpg

Dengan pemeri atau dialog yang sesuai dan tepat dengan ilustrasi, pembaca dapatlah memahami ilustrasi yang dihasilkan oleh pelukis walaupun dengan gaya surealisme. Hal ini membantu pembaca kanak-kanak dan remaja yang belum kenal dengan Hikayat Patani untuk mengetahui bahawa e-komik ini mengisahkan tentang sejarah ataupun peristiwa yang berlaku suatu ketika dahulu di sebuah negeri bernama Patani yang terletaknya dalam Alam Melayu. Malah, pembaca juga mengalami pengalaman imbas kembali melalui ilustrasi dengan gaya surealisme walaupun secara tidak sedar.

Seterusnya, prinsip reka bentuk dalam komik turut terdapat dalam e-komik Hikayat Patani: Putera Pewaris Kerajaan seperti dalam Rajah 14 berikut:

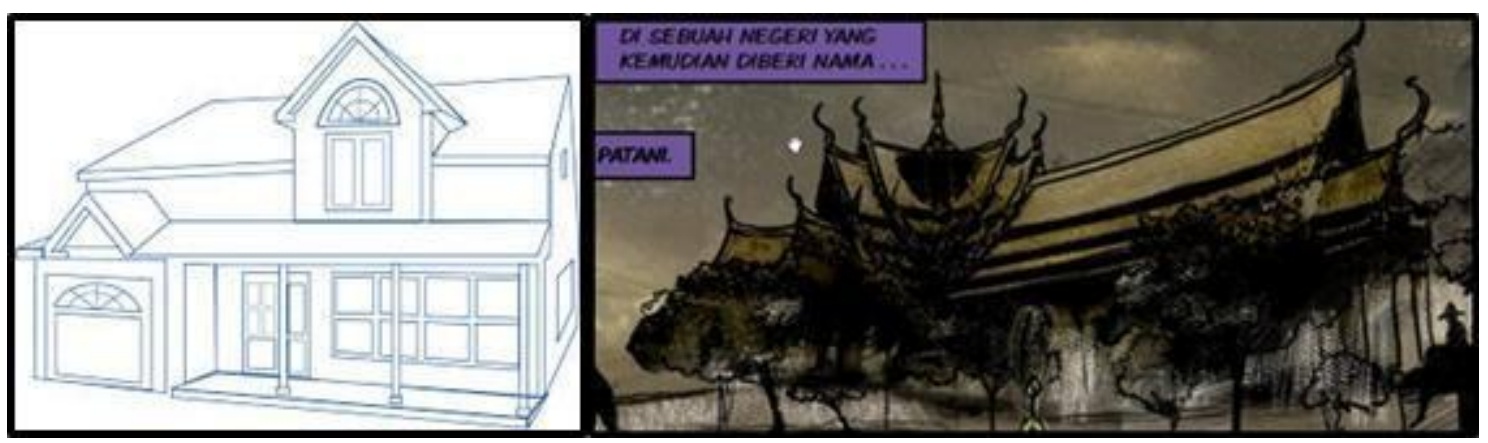

Rajah 14: Prinsip reka bentuk dalam e-komik Hikayat Patani: Putera Pewaris Kerajaan. Sumber: https://en.wikipedia.org/wiki/Shatter (digital comic)\#/media/File:Shatter (digital comic).jpg

Melalui Rajah 14, prinsip reka bentuk telah digunakan dalam menggambarkan institusi beraja Melayu di Negeri Patani. Kedua-dua imej dalam Rajah 14, memperlihatkan reka bentuk yang sama. Walau bagaimanapun, kehalusan reka bentuk, iaitu melibatkan "shading" dan juga garisan telah pun membezakan maksud yang diterima oleh khalayak pembaca, iaitu rumah dan istana. Pembaca e-komik ini terutamanya dalam kalangan kanak-kanak akan mengalami pengalaman dan pengetahuan yang baharu. Kanak-kanak akan faham, Raja tinggal di istana, tidak seperti tempat tinggal rakyat biasa. 
Selain itu, melalui analisis yang dilakukan, didapati prinsip gerak isyarat telah diguna pakai dalam e-komik Hikayat Patani: Putera Pewaris Kerajaan. Ia dihadirkan semasa Raja Phaya Tu Kerub sedang gering seperti yang dapat diteliti melalui Rajah 15 berikut:

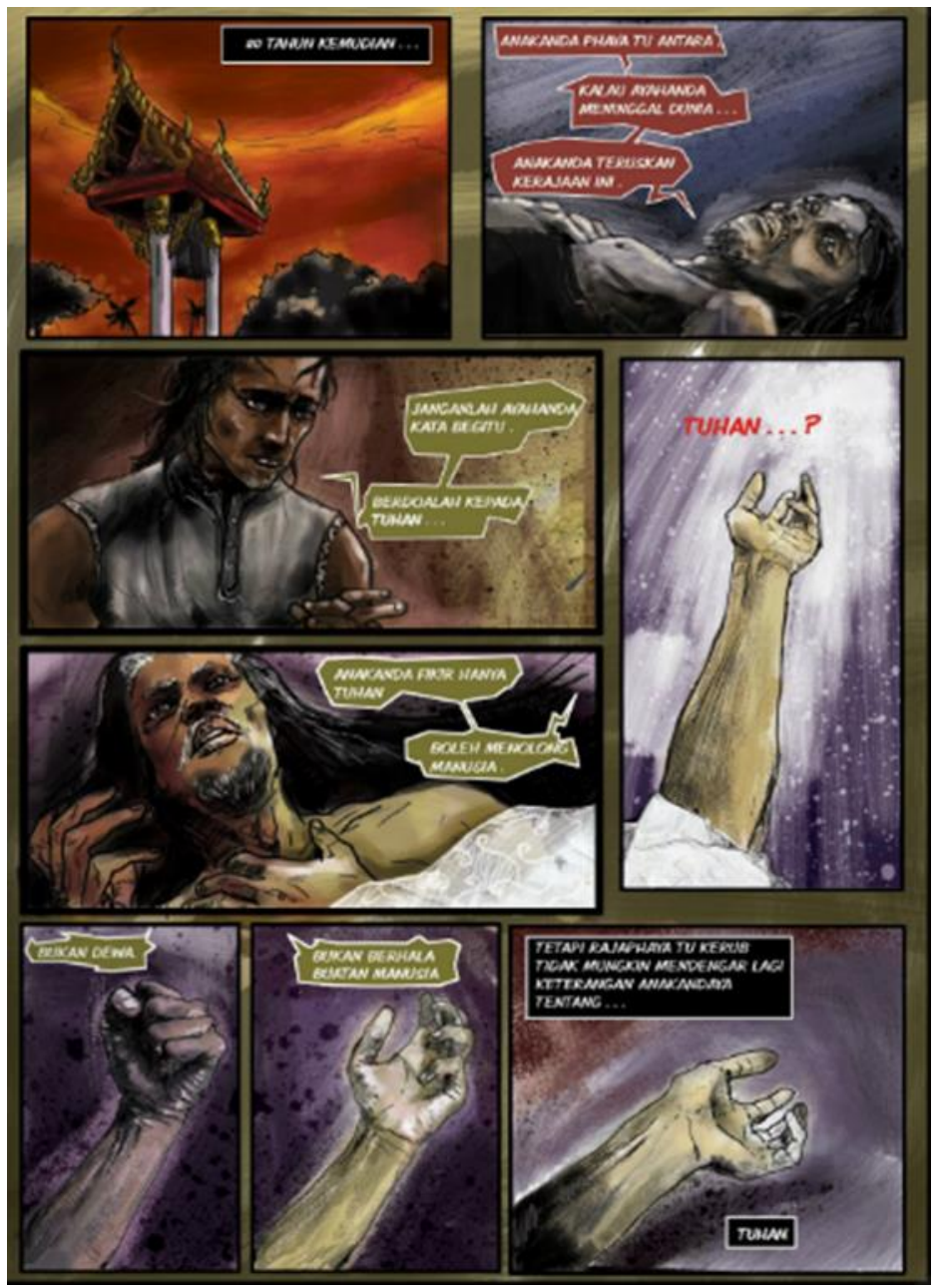

Rajah 15: Prinsip gerak isyarat banyak ditemui dalam panel-panel pada halaman 5 e-komik. Sumber: https://en.wikipedia.org/wiki/Shatter_digital_comic)\#/media/File:Shatter_digital_comic).jpg

Melalui prinsip gerak isyarat yang ada pembaca dapat memahami gambaran aksi dan pergerakan yang sedang dialami atau dilakukan oleh karakter yang telah dilukis oleh pelukis ilustrasi. Merujuk kepada Rajah 15, pelukis ilustrasi telah menekankan prinsip gerak isyarat dalam usaha menyampaikan makna. Ilustrasi anatomi genggaman tangan Raja Phya Tu Kerub, iaitu yang sedang semakin terbuka pada setiap panel, telah memberi makna bahawa baginda sudah semakin lemah atau gering. Panel terakhir menunjukkan bahawasanya baginda telah mangkat. Justeru, pembaca dapat memahami kemangkatan Raja Phya Tu Kerub yang secara langsung menyebabkan peralihan tampuk pemerintahan Kota Mahligai kepada Raja Phaya Tu Naqpa.

Di samping itu, prinsip ekspresi turut ditekankan dalam penghasilan e-komik Hikayat Patani: Putera Pewaris Kerajaan. Menerusi prinsip ekspresi, khalayak pembaca dapat untuk memahami emosi yang sedang dialami oleh semua karakter yang telah dilukis oleh pelukis ilustrasi. Merujuk kepada Rajah 16 di bawah, dapat difahami gambaran karakter Raja Phaya Tu Kerub sedang gering melalui ekspresi wajah yang telah diilustrasikan oleh pelukis. Tanpa lukisan ekspresi yang jelas, pembaca tidak akan yakin dengan dialog yang disampaikan oleh 
karakter. Prinsip ekspresi ini turut melibatkan kehalusan reka bentuk, iaitu "shading" dan garisan. Gabungan antara kedua-dua prinsip ini memberikan identiti dan makna yang jelas kepada pembaca.

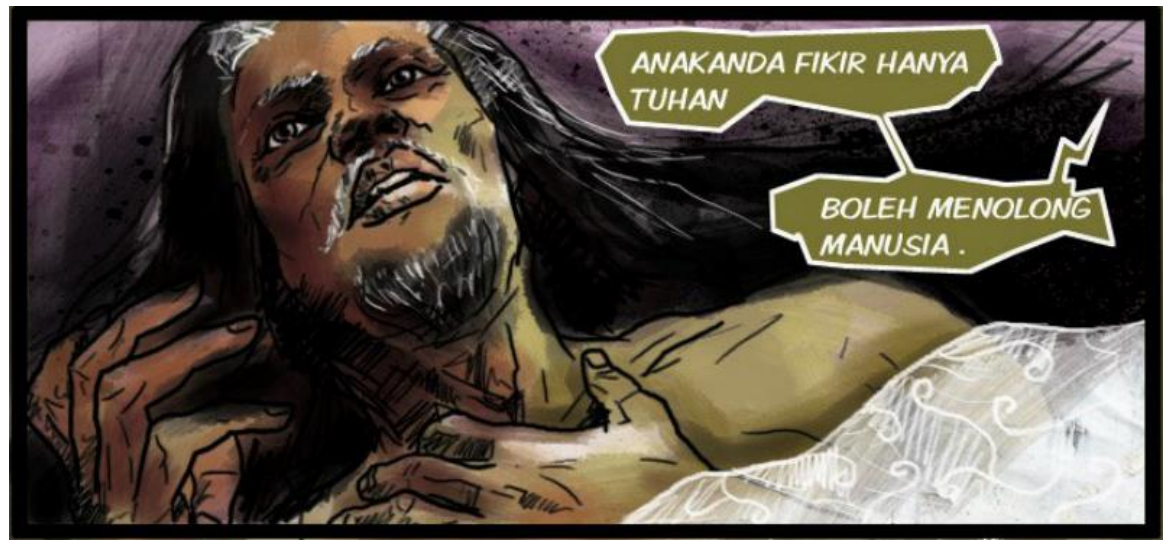

Rajah 16: Ilustrasi menggambarkan ekspresi wajah pada karakter Raja Phaya Tu Kerub.

Sumber: https://en.wikipedia.org/wiki/Shatter (digital comic)\#/media/File:Shatter (digital comic).jpg

\section{Kemunculan Kerajaan Melayu Patani}

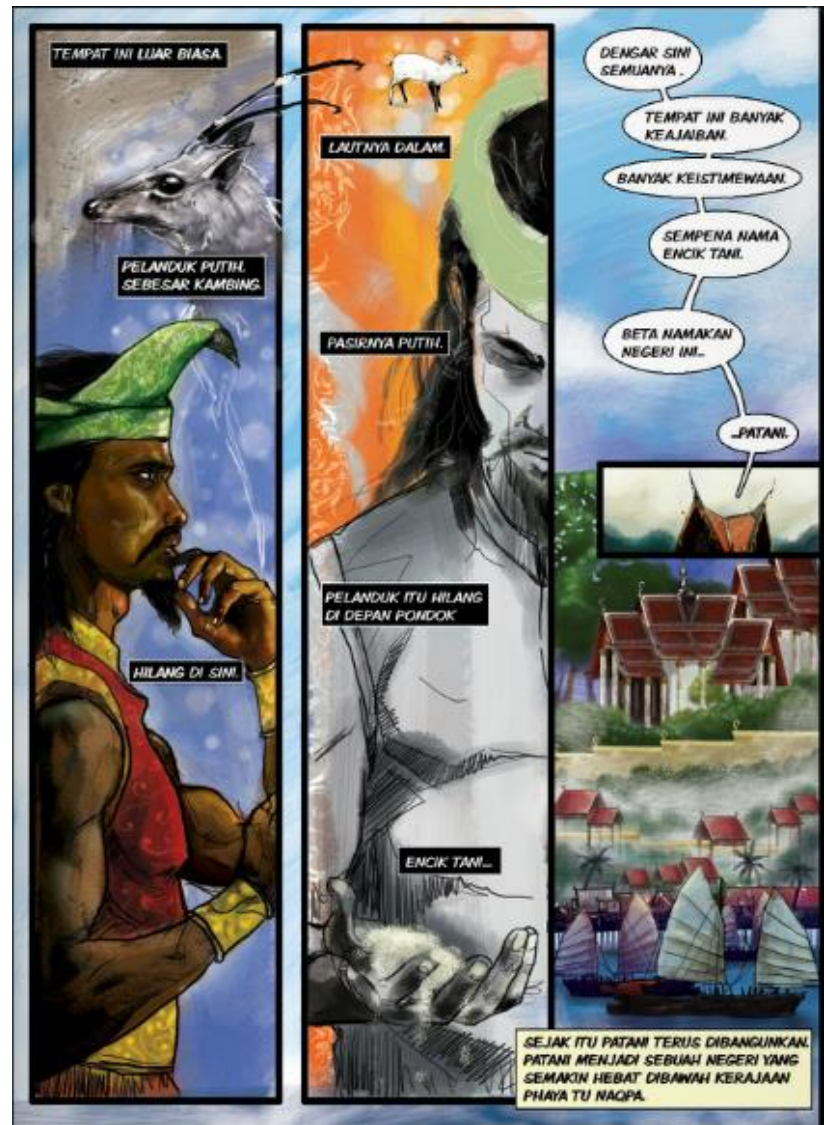

Rajah 17: Peristiwa pembukaan Negeri Patani pada halaman 11.

Sumber: https://en.wikipedia.org/wiki/Shatter_(digital_comic)\#/media/File:Shatter (digital_comic).jpg 
Halaman 11 dalam e-komik Hikayat Patani: Putera Pewaris Kerajaan, telah memaparkan kepada khalayak pembaca tentang kemunculan kerajaan Melayu Patani. Dalam halaman ini, pelukis ilustrasi kekal dengan gaya surealisme yang digunakan dari halaman pertama e-komik ini.

Implikasi dan tujuan ilustrasi dengan gaya ini tetap sama dan tidak berubah seperti yang telah diterangkan pada awalnya. Namun, tidak semua pembaca dapat menimba atau menaakul pengalaman estetika yang jelas. Meskipun begitu, pelukis ilustrasi tetap ingin terus menyajikan e-komik kepada khalayak dengan mutu seni yang tinggi. Dalam perkara ini, unsur ilustrasi dan bahasa bertulis sekali lagi memainkan peranan penting dalam memperkukuhkan makna yang ingin disampaikan kepada khalayak pembaca. Malah, prinsip-prinsip komik juga perlu ditekankan seperti mana yang telah dibincangkan.

Merujuk kepada Rajah 17, pembaca akan membaca halaman 11 e-komik ini melalui susunan panel, iaitu dari kiri ke kanan. Susunan panel dengan pemilihan ilustrasi dan juga dialog situasi yang sesuai menjadikan proses penceritaan menjadi lancar dan mudah. Melalui prinsip transisi yang dipaparkan pada halaman 11 (Rajah 17), pembaca akan melihat karakter Raja Phaya Tu Naqpa sedang ligat berfikir tentang kejadian sewaktu berburu, keistimewaan latar tempat dan pengisytiharan pembukaan kerajaan Melayu Patani. Semua makna yang terdapat diperoleh oleh pembaca daripada penyusunan panel yang sesuai dan tepat. Malah, ilustrasi memainkan peranan penting bagi melengkapkan makna yang diberikan oleh teks dalam panel-panel yang dihasilkan. Misalnya, tanpa ilustrasi pelanduk putih, pembaca kanakkanak terutamanya tidak dapat membayangkan rupa haiwan mistikal itu jika hanya teks sahaja yang dihadirkan dalam panel 1 Rajah 17. Seterusnya, dalam panel 3 Rajah 17, pelukis ilustrasi telah menghadirkan ilustrasi kapal-kapal di pelabuhan bagi memberikan makna terhadap teks yang ditulis berkaitan pembukaan Negeri Patani yang semakin bertambah maju. Justeru, ilustrasi dan teks mempunyai hubungan timbal balik, iaitu ilustrasi membantu menjelaskan makna kepada teks dan sebaliknya. Hal ini adalah amatlah ditekankan dalam penghasilan komik bagi membantu proses pembacaan (Roslina, Roswati, Hazlina \& Nor Shahila, 2018).

Berdasarkan kepada analisis tekstual yang dilakukan, jelas bahawa kelima-lima prinsip komik yang dikemukakan oleh Hall (2014) adalah wujud dalam e-komik Hikayat Patani: Putera Pewaris Kerajaan. E-komik ini juga dihasilkan dengan kepatuhan yang tinggi terhadap teks yang dijadikan sumber, iaitu Hikayat Patani. Oleh yang demikian, tiadanya penyelewengan peristiwa sejarah dilakukan dalam e-komik ini. Selain itu, teknik-teknik penghasilan ilustrasi dalam e-komik ini juga tidak mendapat pengaruh daripada manga dan sebagainya. E-komik ini hadir dengan jati diri tersendiri dalam memastikan sejarah Melayu Patani itu dapat untuk disampaikan dengan pemaknaan yang tepat. Setiap karakter dan latar yang dipersembahkan oleh pelukis ilustrasi adalah jelas menonjolkan ciri-ciri kemelayuan.

\section{ANALISIS KEPENTINGAN E-KOMIK HIKAYAT PATANI: PUTERA PEWARIS KERAJAAN}

Masyarakat Malaysia secara umumnya melabelkan komik sebagai bahan bacaan picisan. Komik sering dikatakan tidak berfaedah kerana kandungannya didakwa mempunyai lukisan yang tidak sopan, bahasa yang kesat dan aksi-aksi yang ganas. Dalam erti kata lain, kesemua komik yang ada telah pun diletakkan dalam kelas yang sama. Menurut Julina dan Md. Salleh (2020), perkara ini terjadi kerana kegagalan masyarakat tempatan dalam menangkap makna di sebalik cerita-cerita yang disampaikan dalam komik. Tanpa pertimbangan yang rasional, komik terus diberikan tohmahan sebagai bahan bacaan yang tidak mempunyai nilai keilmuan. Hal ini sekaligus telah menyebabkan ataupun menjadi salah satu faktor kemerosotan industri 
pembukuan komik di Malaysia. Bagi Muliyadi (2015), perkara ini membuatkan golongan anak muda di Malaysia kurang gemar menjadi kartunis dan seterusnya membuatkan industri komik tempatan ketandusan bakat-bakat baharu. Walau bagaimanapun, timbul persoalan mengapa masyarakat di negara-negara seperti Jepun dan Amerika Syarikat tidak mempunyai persepsi atau tanggapan yang serupa dengan masyarakat di Malaysia? Sedangkan negara-negara ini lebih maju dari segi ekonomi dan terkenal dengan seni budaya yang berjaya mempengaruhi dunia luar.

Noor Azleenda (2012) dalam penulisannya, iaitu "Komik Bukan Sekadar Bahan Bacaan Picisan" mengatakan bahawa negara-negara maju seperti Jepun, Korea Selatan dan Australia telah menjadikan komik sebagai bahan bantu mengajar di sekolah. Di Jepun, penggunaan komik sebagai bahan dalam pembelajaran di peringkat telah diamalkan sejak pasca Perang Dunia Ke-2 lagi (Swift, 2009). Melalui komik manga, tokoh-tokoh unggul mereka dalam sejarah dan sastera juga diangkat supaya kanak-kanak dan remaja menyedari akan asal usul bangsa mereka dan secara tidak langsung menanam sifat jati diri yang tinggi dalam generasi muda (Swift, 2009). Menurut Yamaguchi (2019), peristiwa pengeboman di Hiroshima dan juga Nagasaki turut diajar menggunakan komik agar kanak-kanak memahami tentang apa yang berlaku pada waktu itu. Malah, kanak-kanak sekolah juga diminta untuk melukis manga bagi menajamkan kemahiran melukis mereka (Yamaguchi, 2019). Dalam perkembangan terbaharu komik Doraemon telah digunakan di sekolah rendah untuk mengajar kanak-kanak tentang etika dan moral (Yamaguchi, 2019).

Secara psikologi, memang benar golongan kanak-kanak dan juga remaja lebih menggemari bahan bacaan seperti komik berbanding bahan bacaan yang hanya menyajikan teks bertulis semata-mata (Wiegers, 2015). Hal ini demikian kerana, ciri-ciri lukisan karakter dalam komik yang memiliki warna, struktur badan dan ekspresi wajah lebih menarik minat pembaca berbanding teks bertulis. Kanak-kanak dapat memberikan tumpuan yang lebih terhadap bahan bacaan yang memiliki ciri-ciri tersebut. Selain kanak-kanak dan remaja, komik juga telah membantu para pelajar universiti dalam proses pembelajaran seperti mana yang telah dibuktikan dalam kajian terhadap pelajar UM dan UPM oleh Roslina, Roswati, Hazlina dan Nor Shahila (2018). Oleh yang demikian, adalah sama sekali tidak mustahil e-komik seperti Hikayat Patani: Putera Pewaris Kerajaan dapat memainkan peranan yang sama seperti yang dilakukan di negara-negara maju.

Masyarakat Malaysia sewajarnya harus sedar tentang peranan komik dalam menarik minat membaca dalam kalangan kanak-kanak dan remaja. Dalam hal ini, isu kandungan komik seharusnya dibincangkan dan ditapis oleh pembaca, bukannya terus melabel bahan komik dengan persepsi-persepsi yang negatif. Dalam konteks inilah DBP telah pun membangunkan e-komik, iaitu Hikayat Patani: Putera Pewaris Kerajaan. Kandungan e-komik ini amat diyakini mempunyai nilai keilmuan dan informasi yang berguna kepada pembaca. Lebih-lebih lagi kerana penulisnya merupakan seorang Sasterawan Negara. Pelukis komiknya juga anak tempatan yang terkenal. Malah, penerbit komik digital ini pula ialah sebuah jabatan kerajaan Malaysia yang sudah tentu mahu menjaga mutu dan juga kandungan yang terdapat dalam setiap terbitannya. Di sini pentingnya e-komik Hikayat Patani: Putera Pewaris Kerajaan untuk menjadi kayu ukur atau asas kepada penghasilan e-komik berasaskan sumber sejarah pada masa akan datang oleh mana-mana pihak. 
Selain itu, dengan mewujudkan e-komik Hikayat Patani: Putera Pewaris Kerajaan ini, anak-anak atau generasi muda bukan sahaja lebih berminat untuk membaca, malah mereka juga dapat mengetahui sejarah dan asal usul kerajaan Patani. Sempadan yang ada kini di antara Malaysia dengan Negeri Patani (sekarang dalam negara Thailand) sudah menyebabkan generasi muda tidak tahu bahawa Negeri Patani merupakan sebuah kerajaan Melayu yang ulung suatu ketika dahulu. Orang Patani itu sering dianggap sebagai Siam seperti yang telah dibincangkan. Oleh yang demikian, menerusi e-komik ini generasi muda dapat menanggapi sejarah menerusi bacaan secara tidak langsung terhadap teks hikayat. Dalam erti kata lain, teks-teks hikayat ini diperkenalkan kepada kanak-kanak pada peringkat lebih awal dengan medium yang lebih menarik, iaitu e-komik. Setelah mengetahui kewujudan teks-teks hikayat ini melalui e-komik, pastinya mereka akan menaakul sejarah yang diperoleh untuk panduan masa hadapan. Memetik kata-kata Christopher Bram (2016, hlm.11) dalam bukunya The Art of History "history is good medicine...visits to the past are good for us", iaitu sejarah adalah ubat atau penawar yang baik, khususnya kepada peradaban manusia. Sejarah itu dikatakan ubat yang baik kerana melalui sejarah manusia akan dapat belajar daripada kesilapan lalu dan juga mengambil teladan daripada peristiwa-peristiwa sejarah yang telah meruntuhkan sesebuah tamadun bangsa. Sejarah masa lalu juga amat penting dalam menentukan corak pemikiran manusia, gaya hidup atau budaya yang diamalkannya kerana manusia perlu bercermin pada sejarah untuk kehidupan hari akan datang (Bram, 2016). Maka, usaha DBP mengambil teks hikayat sebagai sumber penghasilan e-komik adalah bertepatan sekali.

Seterusnya, selain membekalkan ilmu dan sejarah yang berguna kepada pembaca, ekomik membuatkan pembacaan tentang peradaban bangsa menjadi lebih santai dan menarik bagi kanak-kanak. Menurut Bram (2016), apa jua bentuk adaptasi ataupun transformasi yang dilakukan terhadap bahan sejarah seperti komik, filem dan sebagainya, menjadikan sejarah yang kaku dapat diwarnai dengan nafas baharu. Hal ini disebabkan oleh ada pelbagai unsurunsur baharu, misalnya ilustrasi-ilustrasi bagi e-komik yang menghidupkan dan mencantikkan lagi jalan cerita yang dihasilkan oleh penulis. Malah, e-komik juga membuatkan murid-murid sekolah atau kanak-kanak berfikir secara kreatif dan kritis melalui lakaran visual serta dialog yang disampaikan. Justeru, e-komik seperti Hikayat Patani: Putera Pewaris Kerajaan ini dapat menembusi minat kanak-kanak dan remaja untuk menangkap nilai-nilai peradaban bangsa melalui jalan cerita dan ilustrasi yang dihidangkan.

Di samping itu, kepentingan lain e-komik Hikayat Patani: Putera Pewaris Kerajaan adalah membuatkan masyarakat dan generasi muda di Negeri Patani bebas untuk membuka atau mengakses e-komik ini secara dalam talian secara percuma tanpa mengira masa. Hal ini dikatakan penting kerana jika diterbitkan dalam bentuk bercetak, ada kemungkinan ia akan disekat dan dilarang untuk dijual di Negeri Patani. Berlakunya keadaan ini kerana kandungan e-komik ini menceritakan sejarah asal usul Negeri Patani yang telah lama mahu dipadamkan oleh kerajaan Thailand. Penyebarannya dikhuatiri dapat membangkitkan semangat nasionalis dalam diri masyarakat Melayu Patani, lantas berjuang menuntut kemerdekaan (Mohamed Nazreen, Muhammad Izzat, \& Md. Salleh, 2017).

\section{ANALISIS CABARAN E-KOMIK HIKAYAT PATANI: PUTERA PEWARIS KERAJAAN}

Dalam mengorak langkah baharu, sesuatu usaha itu pasti menghadapi cabaran dari pelbagai segi. Masyarakat umumnya sukar untuk menerima pendekatan baharu, khususnya yang mana melibatkan warisan dan kebudayaan. Misalnya, pendekatan yang digunakan DBP dalam usaha memperkenalkan e-komik Hikayat Patani: Putera Pewaris Kerajaan. Karya agung biasanya sukar untuk diadaptasi kerana mempunyai nilai sejarah yang tinggi (Hadi, 2020). Malah, 
Francois Truffaut (Giddings, 1990, hlm.21), ada menyatakan; "Theoretically, a masterpiece is something that has already found its perfection of form, its definitive form". Oleh yang demikian sebarang bentuk ataupun unsur percanggahan bakal menjemput polemik yang tidak sepatutnya (Hadi, 2020). Pihak penerbit sering dikatakan hanya mahu mengaut untung daripada teks-teks yang ada. Namun, usaha oleh DBP ini jelas bukan bertujuan untuk mengaut keuntungan daripada peminat dan pembaca komik kerana e-komik ini tidak dipasarkan. Malah, e-komik ini dipaparkan kepada umum secara percuma dengan mutu visualnya juga berkualiti tinggi. Jalan ceritanya juga menepati apa yang terdapat dalam teks Hikayat Patani seperti yang telah dinyatakan.

Selain itu, e-komik Hikayat Patani: Putera Pewaris Kerajaan ini turut menghadapi cabaran berkaitan kekurangan pembaca sasaran. Menurut Hassan (2018) cabaran kekurangan pembaca sasaran ini berlaku kerana e-komik sukar untuk diakses kerana jaringan internet yang tidak stabil dari pihak DBP. Ada harinya e-komik ini boleh diakses, ada harinya langsung tidak boleh diakses (Hassan, 2018). Kekangan dalam mengakses e-komik ini menyebabkan penyebarannya tersekat-sekat dan tidak begitu meluas Apabila penyebaran ekomik ini tidak meluas, dampak atau kesan yang diharapkan oleh DBP untuk memperkenalkan naskhah Hikayat Patani kepada golongan muda tidak akan tercapai. Oleh itu, DBP seharusnya memperkuatkan jaringan internetnya agar e-komik ini dapat diakses pada bila-bila masa.

\section{KESIMPULAN}

Kesimpulannya, komik merupakan bahan bacaan efektif dalam menyampaikan ilmu dan juga maklumat kepada pembaca. Sifatnya yang menyeronokkan dapat menarik tumpuan pembaca terutamanya remaja dan kanak-kanak. Memandangkan buku-buku cerita dan juga hikayat semakin dipandang sepi, bahan bacaan yang sebegini perlu diperbanyakkan dan terus diguna pakai dalam memperkenalkan cerita-cerita hikayat kepada generasi muda. Walau perit, harus diakui bahawa generasi muda tidak lagi mengejar hikayat-hikayat lama untuk mereka baca, melainkan apabila cerita-cerita ini menarik pada pandangan mereka.

Selain itu, melalui analisis teks tekstual yang dilakukan, kajian mendapat bahawa ekomik Hikayat Patani: Putera Pewaris Kerajaan mempunyai kelima-lima prinsip komik yang telah digariskan oleh Hall (2014), iaitu ekspresi, reka bentuk, gerak isyarat, dialog dan transisi. Perkara ini membuatkan mutu penghasilan e-komik berada pada tahap yang tinggi. Malah, melalui kandungan cerita yang disampaikan, kualiti e-komik ini jauh meninggalkan e-komik lain yang ada dalam pasaran seperti di bawah terbitan Gempak Starz. Teknik penghasilan ilustrasi dalam e-komik juga kuat dengan jati diri tanpa pengaruh luar dalam mencerminkan peradaban bangsa Melayu Patani. Oleh itu, e-komik ini dilihat penting dalam menarik minat generasi muda terhadap teks tradisional Hikayat Patani dan mengetahui sejarah asal usul negeri Patani yang tersembunyi dalam lipatan sejarah. Walau bagaimanapun, terdapat juga cabaran dalam penghasilan e-komik ini, iaitu berkaitan jaringan internet yang lemah dan penerimaan masyarakat. Oleh itu, usaha murni ini perlu mendapatkan sokongan pelbagai pihak agar lebih banyak karya sastera sejarah dapat dibangunkan menjadi e-komik pada masa sekarang dan masa hadapan. 


\section{BIODATA}

Mohamed Nazreen Shahul Hamid, PhD, merupakan pensyarah di Pusat Pengajian Bahasa, Tamadun, dan Falsafah, Universiti Utara Malaysia. Bidang pengkhususannya ialah Teori dan Kritikan Kesusasteraan. Giat melakukan kerja penyelidikan dan penerbitan dalam bidang kesusasteraan, budaya dan media baharu. E-mel: nazreen@uum.edu.my

Muhammad Nur Saiful Ghazali, merupakan graduan sarjana bidang kesusasteraan dari Pusat Pengajian Ilmu Kemanusiaan, Universiti Sains Malaysia. Kini bertugas sebagai guru Bahasa Melayu di Jabatan Bahasa, Maktab Rendah Sains Mara Arau. Giat melakukan penulisan dalam bidang sastera, media dan karya kreatif. E-mel: mnursaiful@mara.gov.my 


\section{RUJUKAN}

Abdul Muati @ Zamri Ahmad. (2015). Keris Melayu semenanjung: Suatu pengenalan. Serdang: Penerbit UPM.

Allen, W. T. (2014). Economics of digital comics. New York: Indignant Media.

Andaq Fithry. (2019). Webcomics in Malaysia - A closer look at Nothingwejun. The Full Frontal. https://thefullfrontal.my/webcomics-in-malaysia-a-closer-look-

Anuar Rihdwan, \& Faisal Jalil. (2010). E-komik Hikayat Patani: Putera pewaris kerajaan. Kuala Lumpur: Dewan Bahasa dan Pustaka. Retrieved from Webtoons. https://www.webtoons.com/en/challenge/hikayat-patani/putera-pewariskerajaan/viewer?title no $=584969$ \&episode no=1\&webtoon-platform-redirect=true

Bram, C. (2016). The art of history: Unlocking the past in fiction and nonfiction. Minnesota: Graywolf Press.

Chelsea, D. (2001). Perspective! For comic book artists. NY: Watson-Guptill Publications. Eisner, W. (2008). Comics and sequential art. New York: Poorhouse Press.

Eizah Mat Hussain. (2019). Simbol dan makna dalam pantun Melayu. Kuala Lumpur: ITBM. Giddings, R. (1990). The classic novel form page to screen. Manchester University Press. Ibrahim Ismail. (1987). Sejarah Kedah sepintas Ialu. Penerbitan Universiti Utara Malaysia. Hadi Akhbar Dahlan. (2020). Kepentingan penghasilan komik pendidikan dalam acuan tempatan. Forum Komunikasi, 15(2), 71-86.

Hall, C. M. (2014). A comic book for beginner. New York: HarperCollins Publisher Inc.

Hamidah Abdul Wahab. (2011). Bahasa pemersatu bangsa: Ragam bahasa dalam komik. MANU, 17, 21-38.

Hassan Alias. (2018). Hikayat dalam bentuk e-Komik. Berita Harian, hlm.15.

Julina Ismail@Kamal, \& Md. Salleh Yaapar. (2020). Komik selendang Siti Rugayah: Suatu bacaan hermeneutik kerohanian. Malay Literature, 33(1), 67-82.

Kirchoff, S. J., \& Cook, P. M. (2019). Perspectives on digital comics. McFarland \& Co Inc. Louie, S. (2014). Write and draw your own comics. London: Usborne Publishing Ltd. McCloud, S. (1993). Understanding comics: The invisible art. HarperCollins Publisher Inc. McCloud, S. (2001). Reinventing comics. New York: HarperCollins Publisher Inc.

McCloud, S. (2011). Making comics: Storytelling secrets of comics, manga and graphic novels. New York: HarperCollins Publisher Inc.

Miller, J. J. (2013, February 17). Overall print comics market topped \$700 million in 2012. Comichron. https://comichron.com/blog/2013/02/17/overall-print-comics-markettopped-700/

Mohamed Nazreen Shahul Hamid, Muhammad Izzat Md Isa, \& Md. Salleh Yaapar. (2017). Penghijrahan dan pencarian identiti Melayu Patani diaspora dalam cerpen Isma Ae Mohamad. Malay Literature, 30(2), 258-276.

Mohamed Nazreen Shahul Hamid. (2020). Perjuangan rakyat Patani: Kajian perang gerila dalam novel-novel terpilih [Tesis Doktor Falsafah]. Universiti Sains Malaysia.

Mohd Aswari Md Salleh, \& Jasni Dolah. (2016). Penilaian bahasa visual terhadap faktor penglibatan pembaca komik Melayu. Conference Proceeding 2th International Conference on Creative Media, Design \& Technology (REKA 2016) (hlm. 189-200). Pulau Pinang: Universiti Sains Malaysia.

Mohd Zamberi Abdul Malek. (2017). Biografi Tengku Abdul Kadir Kamaruddeen Raja Patani terakhir. Bangi: Penerbit UKM.

Muliyadi Mahamood. (2015). Kartun dan kartunis di Malaysia. Kuala Lumpur: ITBM. 
Nasihah Hashim, Noor Aida Mahmor, Ainal Akmar, \& Maizatul Azura Yahya. (2016). Bahasa slanga dalam komik kanak-kanak. Proceeding 2nd International Convention on Islam, Science \& Education (hlm. 13-21). Sintok: Universiti Utara Malaysia.

Nik Anuar Nik Mahmud. (2006). Sejarah perjuangan Melayu Patani 1785-1954. Bangi: Penerbit UKM.

Noor Azleenda Abdul Hadi. (2012). Komik bukan sekadar bahan bacaan picisan. Scribd. https://www.scribd.com/doc/149009474/Komik-Bukan-Sekadar-Bahan-BacaanPicisan

Nurul Syazwani Mohd Dahalan, \& Wan Hasmah Wan Teh. (2020). Pertembungan nilai desa dan kita dalam komik Budak Kampung dan Mat Som (The clash of rural and urban values in the comic books Budak Kampung and Mat Som). Malay Literature, 33(2), 212-242.

Petersen, R. S. (2011). Comics, manga and graphic novels: A history of graphic narratives. California: ABC-CLIO.

Roslina Mamat, Nor Shahila Mansor, Hazlina Abdul Hamid, \& Normaliza Abd Rahim. (2015). Manga dan dojinshi Malaysia: Persamaan dan perbezaan ciri-ciri luaran karikatur. Jurnal Komunikasi: Malaysian Journal of Communication, 31(2), 477-492.

Roslina Mamat, Normaliza Abd Rahim, Nik Rafidah Nik Muhamad Affendi, \& Nik Rafidah Nik Muhammad Affendi. (2019). Perkembangan komik dan animasi: Satu kajian perbandingan antara Melayu dan Jepun. Jurnal Komunikasi: Malaysian Journal of Communication, 35(2) 260-276.

Roslina Mamat, Roswati Abdul Rashid, Hazlina Abdul Halim, \& Nor Shahila Mansor. (2018). Penggunaan manga dan anime sebagai media pembelajaran dalam kalangan pelajar bahasa Jepun di universiti awam Malaysia. Jurnal Komunikasi: Malaysian Journal of Communication, 34(3), 298-313.

Sofyan Salam, Sukarman, Hasnawati, \& Muhammad Muhaemin. (2020). Pengetahuan dasar seni rupa. Makassar: Badan Penerbitan UNM.

Styles, H. E. (2019). Comic in new line. London: Fine Publisher.

Swift, M. (2009, October). In Japan manga teaches though lesson. ASCD: Education Update 51(10). http://www.ascd.org/education/oct09/vol51/num10/In-Japan-Manga.aspx

Teeuw, A., \& Wyat, D. K. (1970). Hikayat Patani the story of Patani. Nijhof: The Hague.

Thomspon, J. (2012, January 23). Why manga publishing is dying (and how it could get better). Gizmodo. https://io9.gizmodo.com/why-manga-publishing-is-dying-5874951

Wiegers, P. G. (2015) Comic strips help children understand medical research. Patient Education and Counselling, 98, 518-524.

Yamaguchi, K. (2019). Japan uses Doraemon, comic characters for children`s ethics education. CBCP News. https://cbcpnews.net/cbcpnews/japan-uses-doraemon-comiccharacters-for-childrens-ethics-education/ 